Review

\title{
Protection Coordination of Properly Sized and Placed Distributed Generations-Methods, Applications and Future Scope
}

\author{
Sunny Katyara ${ }^{1, *}$,Lukasz Staszewski ${ }^{2}$ and Zbigniew Leonowicz ${ }^{2, *}$ \\ 1 Sukkur IBA University, Airport Road, Delhi Muslim Housing Society, Sukkur, Sindh 65200, Pakistan \\ 2 Faculty of Electrical Engineering, Wroclaw University of Science and Technology, W. Wyspianskiego 27, \\ 50-570 Wroclaw, Poland; lukasz.staszewski@pwr.edu.pl \\ * Correspondence: sunny.katyara@iba-suk.edu.pk (S.K.); zbigniew.leonowicz@pwr.edu.pl (Z.L.); \\ Tel.: +48-71-320-2626
}

\begin{abstract}
The radial distribution networks are designed for unidirectional power flows and are passive in nature. However, with the penetration of Distributed Generation (DG), the power flow becomes bidirectional and the network becomes active. The integration of DGs into distribution network creates many issues with: system stability, protection coordination, power quality, islanding, proper placement and sizing etc. Among these issues, the two most significant are optimal sizing and placement of DGs and their protection coordination in utility network. The proper coordination of relays with high penetration of DGs placed at optimal location increases the availability and reliability of the network during abnormal operating conditions.

This research addresses most of the available methods for efficient sizing and placement of DGs in distribution system (numerical, analytical and heuristic) as well as the developed protection coordination techniques for utility networks in the presence of DGs (Artificial Intelligence (AI), adaptive and non-adaptive, multi-agent, hybrid). This paper indicates the possible research gaps and highlights the applications possibilities and methods' limitations in the area of DGs.
\end{abstract}

Keywords: Index Terms-Distributed Generation; protection coordination; optimal DG location; optimal DG sizing

\section{Introduction}

Distributed generation (DG) has gained enormous popularity due to its modularity, ease of deployment, operation and control. The term DG is given to the production of electricity near the load center. The decentralized nature of distributed generation makes the basis for micro-grids, where the concept of centralized generation and control does not exist anymore and leads to the smart grid solutions [1]. DG technology mostly involves Renewable Energy Sources (RES) and cogeneration. The integration of DGs into distribution network may pose both positive and negative impact depending upon the characteristics of distribution network and the DG itself. The positive impacts of DG installation are: power loss reduction, voltage profile and reliability improvement, power quality enhancement, no need of new transmission lines installation, and postponement of substation capacity upgrade [2]. Moreover, the DG does not contribute to the greenhouse gases providing clean and efficient energy. The negative effects of DG application are: fault current level increase, discoordination of protection schemes, islanding, bidirectional power flows, and transient instabilities [3].

The optimal size and location of incoming distributed generation are preliminary factors to maximize the system support benefits. The size and location of DG can be decided on the basis of enhancement of one or more distribution network parameters in a way to improve the energy 
efficiency and reduction of negative impacts of the installation [4]. Optimal size and location of DG improves also the performance and operation of whole network. The additional power delivered by DG significantly affects the bus voltage, load characteristics and reliability of the system [5]. Therefore, at the planning stage of distribution system, one of the most crucial and difficult task is to estimate the capacity and location of futures in the network. Different techniques are used for such estimations (e.g., numerical, analytical, and heuristic) and all of them were analyzed in terms of the efficient placement and sizing of DGs.

Since the main function of protection schemes in distribution networks is to immediately isolate the faulty part of the system from the healthy one for the fault occurrence. Thus, mostly overcurrent relays are used in such networks as primary and backup protection. The coordination of overcurrent relays is arranged in such a way that if the fault is not cleared by the primary relay then it should be backed by another relay.

With the introduction of DGs, the existing schemes for distribution network protection become inactive. The intensity of this discoordination depends upon the type, size and location of installed DG [6]. Since the radial utility networks are designed for unidirectional current flows so are protection schemes. With the DG installation, the distribution network forms a closed loop and current flows in both directions thus the existing relays do not protect the system effectively during the faults. One of the possibilities of solving this problem is use of directional overcurrent relays that are able to discriminate between upstream and downstream current flows [7]. Another option is to reset the Time Multiplier Settings (TMS) and Plug Multiplier Settings (PMS) of relays after integration of each DG [8]. However, Distribution System Operators (DSOs) are not in favor of changing the relays settings or network configuration manually. Many adaptive, non-adaptive, multi-agent, Artificial Intelligence (AI), hybrid, etc. techniques are evolved for proper and efficient coordination of relays.

This research addresses most of the available methods for efficient sizing and placement of DGs in distribution system (numerical, analytical, and heuristic) as well as the developed protection coordination techniques for utility networks in the presence of DGs (Artificial Intelligence (AI), adaptive and non-adaptive, multi-agent, hybrid). This paper indicates the possible research gaps and highlights the applications possibilities and methods' limitations in the area of DGs.

\section{Methods for Location and Size of DG}

The methods for location and sizing of DG are divided roughly into three categories: numerical, Analytical, and Heuristic.

\subsection{Objectives}

The objectives of different methods of Optimal Sizing and Location of DG (OSLDG) into distribution network include [9]:

(1) minimizing the power losses,

(2) enhancing the voltage profile of network,

(3) increasing the reliability of network,

(4) improving the loading capacity of network on the basis of voltage constraints,

(5) maximizing the economy of utility operator,

(6) maximizing the MVA capacity requirements of network.

\subsection{Constraints}

The single and multi-objective function of different methods of OSLDG involves many optimization variables with the following possible constraints [10]:

(1) power balance in the network,

(2) fault level and thermal limits,

(3) voltage limits,

(4) reliability and economic limits, 
(5) allowable number of DGs in the network,

(6) power factor limits.

\subsection{DG Technologies}

The devices used for distributed generation include directly connected to the system rotating machines (induction or synchronous), as well as static and rotating devices, which are coupled to the network through electronic converters. Different DG technologies have various influences on the operation, control and stability of a system e.g., the inverter based DGs inject harmonics into the system while the rotating machines create issues for the protection coordination in the distribution network [11]. Most of the effects of distributed generation technologies depend solely upon the size and location of DG installation in the utility network.

\subsection{Numerical Methods}

Numerical methods are based on mathematical programming and analysis and they are listed below. The summary of presented methods is gathered in Table 1.

(1) Gradient search - this method, proposed in [12,13], is used to find the proper size of DGs in mesh networks while considering and ignoring the short circuit capacity limits of the network.

(2) Linear programming - this method, evolved in [14,15], is used to find the optimal location of DG in the distribution network with maximum allowable penetration and energy harvesting from DGs.

(3) Sequential Quadratic Programming (SQP)-it is a second order differential technique, presented in [16], [17], and [18], is used to find the optimal location and size of multiple DGs in distribution network, without considering the short circuit capacity limits of network. The main objective is to reduce overall power losses in the network.

(4) Exhaustive search - a multi-object technique, used in [19-22], used for finding proper location and size of DGs with main focus on reliability improvement and loss minimization at fixed and variable load models. The time-varying behavior of renewable sources and loads were considered in [23].

(5) Ordinal optimization - this method, suggested in [24], is used to find the optimal location and size of DGs in the distribution network making compromise between the power losses minimization and maximizing the allowable penetration of DGs.

(6) Dynamic programming - this method's used to find the optimal size and location of multiple DGs, main objective is to maximize the economy of utility operator at different loading conditions [25].

(7) Nonlinear programming-this technique converts probabilistic model with all network constraints into deterministic model using optimal load flow [26-28]. Mixed-Integer Non-Linear Programming (MINLP) is especially used for proper placement of multiple wind units simultaneously and can also be used for other types of DG but only for single units [29]. An interior point technique is used to find the maximum capacity of utility network for DG integration through optimal load flow analysis [30]. MINLP is used to determine the optimal location and size of inverter based DGs with main objective of enhancing the voltage stability margin of the network [31]. MINLP is used in [32,33] to determine the optimal location and size of DGs in distribution network while considering the variations in the market based energy prices. MINLP implemented in [34] is used during distribution system planning for investigation of the proper location and size of future DGs.

(8) Load model-this method is used to locate and size the DGs in a distribution network having constant and variable power flows. Load models have great significance in stability studies. Three different voltage dependent load models i.e., residential, commercial and industrial are considered for investigation [35].

(9) Protection coordination index-the integration of DGs greatly affects the protection coordination of distribution network. Protection coordination index (PCI) is an indicator which 
represents the change of time coordination between the protection devices with change of penetration level of DGs into distribution network [36].

(10) Contingency analysis - this technique is used to analyze the impact of size and location of DG on distribution system after fault inception. Voltage profile of DG is investigated before and after the occurrence of fault to calculate voltage regulation of system. Based on loading conditions and network configuration the appropriate size and location of DGs can be decided $[37,38]$.

Table 1. Summary of Numerical Methods for Placement and Sizing of DGs.

\begin{tabular}{|c|c|c|c|c|c|}
\hline Technique & Main Features & Merits & Demerits & $\begin{array}{c}\text { Network } \\
\text { Configuration }\end{array}$ & Objectives \\
\hline $\begin{array}{c}\text { Gradient method } \\
{[12,13]}\end{array}$ & $\begin{array}{l}\text { Computing hessian } \\
\text { of second order } \\
\text { network matrix with } \\
\text { and without faulty } \\
\text { conditions }\end{array}$ & $\begin{array}{c}\text { Fast } \\
\text { convergence, } \\
\text { easy } \\
\text { implementation }\end{array}$ & $\begin{array}{c}\text { Diverges at } \\
\text { positive or small } \\
\text { penetrations of } \\
\text { DGs }\end{array}$ & $\begin{array}{l}\text { 6-bus meshed } \\
\text { network }\end{array}$ & $\begin{array}{l}\text { To reduce of } \\
\text { active and } \\
\text { reactive losses } \\
\text { and loading } \\
\text { on the buses }\end{array}$ \\
\hline $\begin{array}{c}\text { Linear } \\
\text { programming } \\
{[14,15]}\end{array}$ & $\begin{array}{l}\text { Limiting voltage, } \\
\text { thermal capacity, } \\
\text { fault level and } \\
\text { ratings of generator } \\
\text { as linear constraints }\end{array}$ & $\begin{array}{l}\text { Can be applied } \\
\text { to any type of } \\
\text { radial network }\end{array}$ & $\begin{array}{l}\text { Does not produce } \\
\text { effective results } \\
\text { with changing } \\
\text { network dynamics }\end{array}$ & $\begin{array}{l}\text { 5-bus radial } \\
\text { distribution } \\
\text { network }\end{array}$ & $\begin{array}{l}\text { To maximize } \\
\text { the generation } \\
\text { capacity of DG }\end{array}$ \\
\hline $\begin{array}{c}\text { Fast sequential } \\
\text { quadratic } \\
\text { programming } \\
{[17]}\end{array}$ & $\begin{array}{c}\text { Formulating } \\
\text { non-linear } \\
\text { optimization } \\
\text { function of network } \\
\text { with nonlinear } \\
\text { inequality and } \\
\text { equality limits } \\
\end{array}$ & $\begin{array}{c}\text { Applicable to } \\
\text { multiple DGs } \\
\text { with unspecified } \\
\text { power factors \& } \\
\text { takes least } \\
\text { computation } \\
\text { time } \\
\end{array}$ & $\begin{array}{l}\text { Not suitable for } \\
\text { network with } \\
\text { changing } \\
\text { dynamics }\end{array}$ & $\begin{array}{l}\text { 69-bus radial } \\
\text { distribution } \\
\text { network }\end{array}$ & $\begin{array}{c}\text { To minimize } \\
\text { the system } \\
\text { power losses }\end{array}$ \\
\hline $\begin{array}{c}\text { Exhaustive search } \\
{[19]}\end{array}$ & $\begin{array}{l}\text { Determining load } \\
\text { conditions of } \\
\text { network at different } \\
\text { DG sizes }\end{array}$ & $\begin{array}{l}\text { Simple, cost } \\
\text { effective } \\
\text { solution }\end{array}$ & $\begin{array}{l}\text { Not suitable for } \\
\text { multiple DGs }\end{array}$ & $\begin{array}{l}3 \text { radial } \\
\text { circuits }\end{array}$ & $\begin{array}{c}\text { To reduce of } \\
\text { power losses } \\
\text { and } \\
\text { improvement } \\
\text { of system } \\
\text { reliability } \\
\end{array}$ \\
\hline $\begin{array}{c}\text { Ordinal } \\
\text { optimization } \\
{[24]}\end{array}$ & $\begin{array}{c}\text { Making tradeoff } \\
\text { between total energy } \\
\text { losses and } \\
\text { generating capacity } \\
\text { of network on the } \\
\text { basis of nonlinear } \\
\text { power flow } \\
\text { calculations }\end{array}$ & $\begin{array}{c}\text { Less } \\
\text { computational } \\
\text { time }\end{array}$ & $\begin{array}{c}\text { Rigorous } \\
\text { calculations and } \\
\text { analysis }\end{array}$ & $\begin{array}{l}\text { 69-bus } \\
\text { distribution } \\
\text { network }\end{array}$ & $\begin{array}{l}\text { To minimize } \\
\text { total energy } \\
\text { losses and } \\
\text { maximizing } \\
\text { generating } \\
\text { capacity }\end{array}$ \\
\hline $\begin{array}{c}\text { Dynamic } \\
\text { programming } \\
{[25]}\end{array}$ & $\begin{array}{l}\text { Maximizing the } \\
\text { economy of utility } \\
\text { network while } \\
\text { considering variable } \\
\text { load models }\end{array}$ & $\begin{array}{c}\text { Enhances } \\
\text { voltage profile } \\
\text { of system, } \\
\text { reduces } \\
\text { computation } \\
\text { time } \\
\end{array}$ & $\begin{array}{l}\text { Not suitable for } \\
\text { dynamic load } \\
\text { conditions }\end{array}$ & $\begin{array}{c}\text { 8-bus radial } \\
\text { network }\end{array}$ & $\begin{array}{c}\text { To minimize } \\
\text { power losses } \\
\text { and improve } \\
\text { reliability of } \\
\text { network }\end{array}$ \\
\hline $\begin{array}{c}\text { Nonlinear } \\
\text { programming } \\
{[26]}\end{array}$ & $\begin{array}{c}\text { Making compromise } \\
\text { between the energy } \\
\text { losses and } \\
\text { generation capacity } \\
\text { with optimal power } \\
\text { flow } \\
\end{array}$ & $\begin{array}{l}\text { Applies to wind } \\
\text { based DGs due } \\
\text { to their time } \\
\text { varying nature }\end{array}$ & $\begin{array}{l}\text { Real time data of } \\
\text { market prices is } \\
\text { necessary as one of } \\
\text { the variables }\end{array}$ & $\begin{array}{l}\text { 61-bus } \\
\text { distribution } \\
\text { network }\end{array}$ & $\begin{array}{l}\text { To minimize } \\
\text { total energy } \\
\text { losses and } \\
\text { maximizing } \\
\text { generating } \\
\text { capacity } \\
\end{array}$ \\
\hline $\begin{array}{c}\text { Load model } \\
{[35]}\end{array}$ & $\begin{array}{c}\text { Maintaining the } \\
\text { voltage at the buses } \\
\text { under prescribed } \\
\text { limits with variable } \\
\text { active and reactive } \\
\text { power }\end{array}$ & $\begin{array}{l}\text { Suitable for } \\
\text { complex } \\
\text { networks with } \\
\text { changing } \\
\text { dynamics }\end{array}$ & $\begin{array}{c}\text { Efficiency of } \\
\text { model is very low } \\
\text { when applied to } \\
\text { ring-main } \\
\text { distribution } \\
\text { networks } \\
\end{array}$ & $\begin{array}{c}\text { 38-bus radial } \\
\text { distribution } \\
\text { network }\end{array}$ & $\begin{array}{c}\text { To reduce of } \\
\text { power losses } \\
\text { and MVA } \\
\text { requirements } \\
\text { of system }\end{array}$ \\
\hline $\begin{array}{c}\begin{array}{c}\text { Protection } \\
\text { coordination }\end{array} \\
\end{array}$ & $\begin{array}{l}\text { Trying to keep the } \\
\text { PCI on the lowest }\end{array}$ & $\begin{array}{l}\text { Used for both } \\
\text { synchronous }\end{array}$ & $\begin{array}{c}\text { Not suitable for } \\
\text { networks with }\end{array}$ & $\begin{array}{c}\text { 14-bus } \\
\text { and30-bus }\end{array}$ & $\begin{array}{l}\text { To reduce } \\
\text { active and }\end{array}$ \\
\hline
\end{tabular}




\begin{tabular}{|c|c|c|c|c|c|}
\hline $\begin{array}{c}\text { index } \\
{[36]}\end{array}$ & $\begin{array}{l}\text { level possible as the } \\
\text { changes in } \\
\text { penetration of DGs } \\
\text { affects the } \\
\text { coordination timing } \\
\text { between the relays }\end{array}$ & $\begin{array}{l}\text { and static DGs. } \\
\text { Helps utility } \\
\text { operator to } \\
\text { determine the } \\
\text { maximum } \\
\text { amount DGs } \\
\text { that can be } \\
\text { added to system }\end{array}$ & $\begin{array}{l}\text { changing } \\
\text { parameters }\end{array}$ & IEEE network & $\begin{array}{l}\text { reactive power } \\
\text { losses, } \\
\text { improve } \\
\text { voltage profile } \\
\text { and restrict } \\
\text { fault level and } \\
\text { thermal limits }\end{array}$ \\
\hline $\begin{array}{c}\text { Contingency } \\
\text { analysis } \\
{[37]}\end{array}$ & $\begin{array}{l}\text { Estimating the } \\
\text { network voltage } \\
\text { profile before and } \\
\text { after faults with and } \\
\text { without DGs }\end{array}$ & $\begin{array}{l}\text { Suitable for } \\
\text { network with } \\
\text { varying load } \\
\text { conditions and } \\
\text { unbalanced } \\
\text { power flows }\end{array}$ & $\begin{array}{l}\text { Unreliable results } \\
\text { on upstream buses }\end{array}$ & $\begin{array}{l}\text { 37-bus IEEE } \\
\text { network }\end{array}$ & $\begin{array}{c}\text { To enhance } \\
\text { voltage profile } \\
\text { of network }\end{array}$ \\
\hline
\end{tabular}

\subsection{Analytical Methods}

These methods are the combination of different techniques used to evaluate the characteristics of network qualitatively and quantitatively. Listed below techniques are based on mathematical expressions. The summary of presented methods is given in Table 2.

(1) $2 / 3$ rule-applied for the distribution networks with uniformly distributed loads. The rule states, the incoming DG should have $2 / 3$ rd capacity of existing distribution network and should be installed at 2/3rd length of a line [39]. Non-effective for non-uniformly distributed loads.

(2) Kalman's filter algorithm - used for finding the optimal size of multiple DGs in combination with Optimal Power Flow (OPF) technique [40]. OPF is used for finding the proper location of all the DGs in the distribution network,then Kalman's filter is applied to find their suitable ratings.

(3) Loss sensitivity factor technique-used for calculation of the equivalent current injections of all DGs on the basis of load flow analysis and for determination of their proper size and location. It employs matrix algebra [41].

(4) Exhaustive load flow technique-based on the power factors of DGs being connected to the distribution network. The computational process is done twice: firstly for losses calculation and secondly for losses reduction [42].

(5) Improved analytical approach - based on the Improved Analytical (IA) expression and used for finding the optimal location and size of multiple DGs. The IA expression is formed by taking into account the active and reactive powers, and power factors of all the DGs [43].

(6) Exact loss formula-analytical method used for development of an expression incorporating the exact relation between the network losses with proper placement and sizing of DGs. Nonlinear curves are obtained between optimal place and size of DG and the network losses [44].

(7) Analytical approach with micro-generation - technique proposed in [45], based on the loss contribution of micro-generators in LV networks at different load conditions. Method used for determination of size, location and number of DGs to be installed in the network based on quantity of avoided losses.

Table 2. Summary of Analytical Methods for Placement and Sizing of DGs.

\begin{tabular}{cccccc}
\hline Technique & Main Features & Merits & Demerits & $\begin{array}{c}\text { Network } \\
\text { Configuration }\end{array}$ & Objectives \\
\hline $\begin{array}{c}\text { 2/3 rule } \\
\text { [39] }\end{array}$ & $\begin{array}{c}\text { 2/3rating of total } \\
\text { capacity of } \\
\text { network at 2/3 } \\
\text { length }\end{array}$ & $\begin{array}{c}\text { Simple, easy to } \\
\text { implement }\end{array}$ & $\begin{array}{c}\text { Not suitable for } \\
\text { networks with } \\
\text { non-uniform } \\
\text { load distribution }\end{array}$ & $\begin{array}{c}\text { 33-bus IEEE } \\
\text { network }\end{array}$ & $\begin{array}{c}\text { To minimize } \\
\text { the power } \\
\text { losses }\end{array}$ \\
\hline $\begin{array}{c}\text { Kalman's } \\
\text { filter } \\
\text { algorithm }\end{array}$ & $\begin{array}{c}\text { Considering total } \\
\text { power loss in } \\
\text { steady state and }\end{array}$ & $\begin{array}{c}\text { Least } \\
\text { computational } \\
\text { times }\end{array}$ & $\begin{array}{c}\text { Pre-processing } \\
\text { data of system } \\
\text { losses and DG }\end{array}$ & $\begin{array}{c}\text { 30-bus IEEE } \\
\text { network }\end{array}$ & To minimize \\
power losses
\end{tabular}




\begin{tabular}{|c|c|c|c|c|c|}
\hline [40] & $\begin{array}{l}\text { sorting out the } \\
\text { best samples from } \\
\text { entire sets of DGs } \\
\text { size and location }\end{array}$ & & $\begin{array}{c}\text { rating are } \\
\text { required }\end{array}$ & & \\
\hline $\begin{array}{c}\text { Loss } \\
\text { sensitivity } \\
\text { factor } \\
\text { technique } \\
\text { [41] }\end{array}$ & $\begin{array}{l}\text { Estimating the } \\
\text { equivalent current } \\
\text { injections of DGs }\end{array}$ & $\begin{array}{c}\text { Easy, fast with } \\
\text { desired } \\
\text { accuracy }\end{array}$ & $\begin{array}{c}\text { Cannot be } \\
\text { applied to } \\
\text { multiple DGs }\end{array}$ & $\begin{array}{c}12,34 \text { and } \\
\text { 69-bus radial } \\
\text { network }\end{array}$ & $\begin{array}{c}\text { To minimize } \\
\text { total power } \\
\text { losses }\end{array}$ \\
\hline $\begin{array}{c}\text { Exhaustive } \\
\text { load flow } \\
\text { technique } \\
\text { [42] }\end{array}$ & $\begin{array}{l}\text { Executing load } \\
\text { flow twice for loss } \\
\text { calculation and } \\
\text { reduction and for } \\
\text { different } \\
\text { configurations } \\
\text { and power factors } \\
\text { of DGs }\end{array}$ & $\begin{array}{l}\text { Effective with } \\
\text { variable load } \\
\text { models }\end{array}$ & $\begin{array}{l}\text { Restricted to } \\
\text { local minimum } \\
\text { value }\end{array}$ & $\begin{array}{c}\text { 16, } 33 \text { and } \\
\text { 69-bus radial } \\
\text { networks }\end{array}$ & $\begin{array}{c}\text { To minimize } \\
\text { total power } \\
\text { losses }\end{array}$ \\
\hline $\begin{array}{c}\text { Improved } \\
\text { analytical } \\
\text { approach } \\
{[43]}\end{array}$ & $\begin{array}{l}\text { Maintaining } \\
\text { balance of active } \\
\text { and reactive } \\
\text { powers in the } \\
\text { network and } \\
\text { analyze the } \\
\text { optimal power } \\
\text { factors of system }\end{array}$ & $\begin{array}{l}\text { Can be used } \\
\text { for any } \\
\text { number of } \\
\text { DGs and has } \\
\text { least } \\
\text { computational } \\
\text { times }\end{array}$ & $\begin{array}{l}\text { Protection } \\
\text { coordination } \\
\text { schemes } \\
\text { becomes } \\
\text { complex }\end{array}$ & $\begin{array}{c}\text { 16-bus, 33-bus } \\
\text { and } 69 \text {-bus } \\
\text { radial } \\
\text { networks }\end{array}$ & $\begin{array}{c}\text { To minimize } \\
\text { total power } \\
\text { losses }\end{array}$ \\
\hline $\begin{array}{l}\text { Exact loss } \\
\text { formula } \\
{[44]}\end{array}$ & $\begin{array}{l}\text { Generating search } \\
\text { tables for different } \\
\text { combinations of } \\
\text { DGs and to } \\
\text { analyze them by } \\
\text { exhaustive load } \\
\text { flow }\end{array}$ & $\begin{array}{c}\text { Can be applied } \\
\text { to complex } \\
\text { networks }\end{array}$ & $\begin{array}{l}\text { Not suitable for } \\
\text { varying } \\
\text { characteristics of } \\
\text { network }\end{array}$ & $\begin{array}{c}\text { 30-bus, } 33 \text {-bus } \\
\text { and } 69 \text {-bus } \\
\text { radial } \\
\text { networks }\end{array}$ & $\begin{array}{c}\text { To minimize } \\
\text { total power } \\
\text { losses }\end{array}$ \\
\hline $\begin{array}{c}\text { Analytical } \\
\text { approach } \\
\text { with } \\
\text { microgenera } \\
\text { tion } \\
\text { [45] }\end{array}$ & $\begin{array}{l}\text { Determining the } \\
\text { amount of } \\
\text { avoided losses on } \\
\text { the basis of type of } \\
\text { load distribution } \\
\text { and penetration of } \\
\text { micro-generation }\end{array}$ & $\begin{array}{c}\text { Highly } \\
\text { recommended } \\
\text { for practical } \\
\text { used }\end{array}$ & $\begin{array}{c}\text { Cannot be } \\
\text { applied to } \\
\text { variable load } \\
\text { models }\end{array}$ & $\begin{array}{c}\text { 34-bus } \\
\text { distribution } \\
\text { network }\end{array}$ & $\begin{array}{c}\text { To minimize } \\
\text { total power } \\
\text { losses }\end{array}$ \\
\hline
\end{tabular}

\subsection{Heuristic Methods}

The heuristic methods are one of the optimization techniques, used to select the best possible solution among the set of different possible results. The summary of described methods is given in Table 3.

(1) Genetic algorithm - a biology-inspired algorithm which uses chromosomes built from genes to find out the optimal location and size of DGs. Using limits of crossover and mutation operator, the best possible solution is obtained [46]. GA used in [47] solves the problem of optimal location and size of DGs based on reliability constraints. GA is employed to solve the optimal location and size of DGs based on different load models [48,49]. In [50] GA is used to maximize the profit of utility operator by deciding proper size and place of DGs in distribution network. Considering power quality issues, GA in combination with decision variable theory is used to find the optimal location and size of DGs [51]. GA in combination with fuzzy theory is used to find proper location and size of DGs with main focus to minimize the power losses [52-55]. A technique with weights considering economy and merits of DGs is solved by GA for their 
optimal location and size [56]. For maximizing the profits of consumers and suppliers GA is applied to find the proper size and location of DGs in distribution network [57]

(2) Particle swarm optimization-method based on natural phenomenon, inspired by social characteristics of bird flocking. The method has many similarities with genetic algorithm [58]. Based on the real and reactive powers injections of DGs, the PSO method is applied to find the proper location of DGs in distribution network [59], whereas based on the power factors of DGs, the PSO algorithm is applied to find the optimal location and size of DGs in distribution network at different load models [60]. Another possibility of considering the harmonic and protection coordination limit, the PSO algorithm is applied for finding the best location and size of rotating and static DGs [61].

(3) Ant colony optimization - method inspired by the behavior of ants which find shortest path to find food [62]. ACO algorithm suggested in [63], is used to find the optimal location and size of DGs while reducing network's active power losses.

(4) Artificial bee colony-technique inspired by the behavior of honey bees called swarms that have intelligent foraging characteristics [64]. ABC algorithm was used in [65] for finding the optimal location and size of DGs on the basis of their power factors and active power losses of network.

(5) Differential evolution - an evolutionary algorithm which optimizes the results in steps on the basis of defined constraints. It may also optimize the objective functions that are not continuous in nature [66]. Based on the voltage sensitivity of buses, the DE is used to compute the best location and size of incoming DGs [67].

(6) Harmony search -a music based heuristic method inspired by the characteristics of music searching for the perfect state of harmony [68]. The problem evolved by loss sensitivity factor technique for determining the proper location of DGs is further solved with use of HS algorithm for finding their optimal sizes [69].

(7) Tabu search-mathematical optimization technique used to find the best possible solution on the basis of user defined rules or search tables [70]. TS algorithm, used in [71,72], for uniformly distributed loads finds the optimal location and size of DGs with defined constraints of loss minimization and voltage profile enhancement.

(8) Big bang big crunch algorithm - is a method inspired from the two theories of the universe, big bang and big crunch. It produces random set of points in the big bang plane and distributes them to the big crunch plane through minimum cost function. BB-BC used in [73], optimally sizes and places the multiples DGs on the basis of performance indices of system.

(9) Practical heuristic algorithms - methods used for learning, solving and discovering solutions without the optimal solution guarantee. However, these techniques are suitable for instant results [74]. A heuristic approach was used in [75] for placing and sizing the DGs on the basis of market based economy and benefits provided to network at peak demands. The heuristic method suggested in [76] for placing only one DG on the basis of its power loss contribution to the network. A heuristic method used in [77] for placing the DG in the network by reducing the cost of network reliability. A heuristic method evolved in [78] was used for placing and sizing the DGs in steps by optimizing the variables of fitness function for maximizing the benefits from DGs introduction into the network.

(10) Hybrid optimization algorithms - many optimization algorithms can be combined together (e.g., PSO, GA, DE, ABC, ACO, etc.), to obtain the best possible solutions utilizing the benefits collectively [79]. A hybrid ACO and $\mathrm{ABC}$ was used in [80] to find the proper location and size of DGs by maximizing the economy and voltage stability of network and reducing power losses and emission rates of associated energy resources. A hybrid taboo search and genetic algorithm is suggested in [81] with major focus on maximizing the voltage profile and decreasing the power losses of investigated network was used for finding the optimal location and size of DGs. A hybrid GA and PSO algorithm, was used in [82] for finding the optimal location and size of multiple DGs. 
Table 3. Summary of Heuristic Methods for Placement and Sizing of DGs.

\begin{tabular}{|c|c|c|c|c|c|}
\hline Technique & Main Features & Merits & Demerits & $\begin{array}{c}\text { Network } \\
\text { Configuration } \\
\end{array}$ & Objectives \\
\hline $\begin{array}{c}\text { Genetic } \\
\text { algorithm } \\
{[46,47]}\end{array}$ & $\begin{array}{l}\text { Determining the } \\
\text { cross over and } \\
\text { mutation operator } \\
\text { of fitness function } \\
\text { for all possible } \\
\text { sets }\end{array}$ & $\begin{array}{l}\text { Robust and } \\
\text { results are not } \\
\text { restricted to } \\
\text { local } \\
\text { minimum } \\
\text { solution }\end{array}$ & $\begin{array}{c}\text { The } \\
\text { convergence } \\
\text { time is high } \\
\text { when precise } \\
\text { results are } \\
\text { needed }\end{array}$ & $\begin{array}{l}\text { 14-bus IEEE } \\
\text { network }\end{array}$ & $\begin{array}{l}\text { To minimize } \\
\text { power losses } \\
\text { and to enhance } \\
\text { voltage profile } \\
\text { of network }\end{array}$ \\
\hline $\begin{array}{c}\text { Particle } \\
\text { swarm } \\
\text { optimizati } \\
\text { on } \\
\text { [60] }\end{array}$ & $\begin{array}{l}\text { Determining the } \\
\text { velocity of particle } \\
\text { and updating its } \\
\text { position in two } \\
\text { dimensional space }\end{array}$ & $\begin{array}{c}\text { Small } \\
\text { computation } \\
\text { time and } \\
\text { ensure greater } \\
\text { stability and } \\
\text { loading of } \\
\text { system }\end{array}$ & $\begin{array}{l}\text { Protection } \\
\text { schemes } \\
\text { become } \\
\text { complex }\end{array}$ & $\begin{array}{l}\text { 38-bus radial } \\
\text { network and } \\
30 \text { bus IEEE } \\
\text { mesh network }\end{array}$ & $\begin{array}{l}\text { To minimize } \\
\text { active and } \\
\text { reactive power } \\
\text { losses, improve } \\
\text { voltage profile } \\
\text { and maintain } \\
\text { fault level of } \\
\text { system }\end{array}$ \\
\hline $\begin{array}{c}\text { Ant colony } \\
\text { optimizati } \\
\text { on } \\
{[63]}\end{array}$ & $\begin{array}{l}\text { Chemical process } \\
\text { based on the social } \\
\text { behavior of agents } \\
\text { to find the shortest } \\
\text { path to efficient } \\
\text { solution using } \\
\text { composite } \\
\text { reliability index }\end{array}$ & $\begin{array}{l}\text { Highly } \\
\text { recommended } \\
\text { for protection } \\
\text { coordination } \\
\text { schemes }\end{array}$ & $\begin{array}{l}\text { Economy of } \\
\text { network is } \\
\text { affected }\end{array}$ & $\begin{array}{l}\text { 69-bus } \\
\text { \&394-bus } \\
\text { distribution } \\
\text { network }\end{array}$ & $\begin{array}{c}\text { To improve the } \\
\text { reliability of } \\
\text { network }\end{array}$ \\
\hline $\begin{array}{c}\text { Artificial } \\
\text { bee colony } \\
\text { [65] }\end{array}$ & $\begin{array}{l}\text { Evaluating the } \\
\text { optimization } \\
\text { population on the } \\
\text { basis of foraging } \\
\text { behavior of } \\
\text { honeybee swarm }\end{array}$ & $\begin{array}{c}\text { Robust, } \\
\text { Efficient and } \\
\text { able to deal } \\
\text { with nonlinear } \\
\text { optimization } \\
\text { problems } \\
\end{array}$ & $\begin{array}{l}\text { Tuning of } \\
\text { parameters is } \\
\text { necessary }\end{array}$ & $\begin{array}{l}\text { 33-bus\&69-bus } \\
\text { radial network }\end{array}$ & $\begin{array}{c}\text { To minimize the } \\
\text { active power } \\
\text { losses }\end{array}$ \\
\hline $\begin{array}{l}\text { Differenti } \\
\text { al } \\
\text { evolution } \\
\text { [67] }\end{array}$ & $\begin{array}{l}\text { Formulation of } \\
\text { continuous } \\
\text { problem based on } \\
\text { payback period } \\
\text { and number of } \\
\text { DGs }\end{array}$ & $\begin{array}{l}\text { Considered } \\
\text { load variations } \\
\text { and can be } \\
\text { applied to any } \\
\text { number of } \\
\text { DGs }\end{array}$ & $\begin{array}{l}\text { Uncertainties } \\
\text { about DGs' } \\
\text { output was not } \\
\text { taken into } \\
\text { account }\end{array}$ & $\begin{array}{c}\text { 19-bus radial } \\
\text { network }\end{array}$ & $\begin{array}{l}\text { To maximize the } \\
\text { economy of fuel }\end{array}$ \\
\hline $\begin{array}{l}\text { Harmony } \\
\text { search } \\
\text { [69] }\end{array}$ & $\begin{array}{l}\text { Calculating loss } \\
\text { sensitivity factor } \\
\text { on the basis of } \\
\text { voltage and } \\
\text { current capacities } \\
\text { of system }\end{array}$ & $\begin{array}{c}\text { Suitable for } \\
\text { simultaneous } \\
\text { reconfiguratio } \\
\mathrm{n} \text { of network } \\
\text { and } \\
\text { installation of } \\
\text { new DGs } \\
\end{array}$ & $\begin{array}{l}\text { Stability } \\
\text { margin of } \\
\text { network gets } \\
\text { affected }\end{array}$ & $\begin{array}{l}\text { 33-bus\&69-bus } \\
\text { radial network }\end{array}$ & $\begin{array}{c}\text { To reduce active } \\
\text { power losses } \\
\text { and to enhance } \\
\text { voltage profile } \\
\text { of network }\end{array}$ \\
\hline $\begin{array}{c}\text { Tabu } \\
\text { search } \\
\text { algorithm } \\
{[71,72]}\end{array}$ & $\begin{array}{l}\text { With known } \\
\text { number of DGs } \\
\text { and their total } \\
\text { capacity, it } \\
\text { determines their } \\
\text { types and } \\
\text { locations }\end{array}$ & $\begin{array}{l}\text { Generates } \\
\text { different } \\
\text { possible } \\
\text { solutions } \\
\text { (neighbors) }\end{array}$ & $\begin{array}{l}\text { Regression is } \\
\text { required to be } \\
\text { computed } \\
\text { again and } \\
\text { again }\end{array}$ & $\begin{array}{l}\text { 37-bus radial } \\
\text { network }\end{array}$ & $\begin{array}{l}\text { To minimize } \\
\text { active power } \\
\text { losses in } \\
\text { distribution } \\
\text { network }\end{array}$ \\
\hline $\begin{array}{l}\text { Big bang } \\
\text { big crunch } \\
\text { algorithm } \\
\text { [73] }\end{array}$ & $\begin{array}{l}\text { Determining the } \\
\text { capacity and } \\
\text { location of DGs } \\
\text { based on the } \\
\text { voltage and } \\
\text { reactive power }\end{array}$ & $\begin{array}{l}\text { Suitable for } \\
\text { balanced and } \\
\text { unbalanced } \\
\text { networks }\end{array}$ & $\begin{array}{c}\text { Only } \\
\text { applicable for } \\
\text { small DG units }\end{array}$ & $\begin{array}{l}\text { 37-bus\& } \\
\text { 69-bus IEEE } \\
\text { network }\end{array}$ & $\begin{array}{c}\text { To minimize the } \\
\text { total power } \\
\text { losses }\end{array}$ \\
\hline
\end{tabular}




\begin{tabular}{|c|c|c|c|c|c|}
\hline & $\begin{array}{l}\text { constraints with } \\
\text { higher flexibility }\end{array}$ & & & & \\
\hline $\begin{array}{c}\text { Practical } \\
\text { heuristic } \\
\text { algorithms } \\
\text { [77] }\end{array}$ & $\begin{array}{l}\text { Calculating } \\
\text { weighting factors } \\
\text { with Newton } \\
\text { Raphson method }\end{array}$ & $\begin{array}{l}\text { Robust and } \\
\text { high precision }\end{array}$ & $\begin{array}{c}\text { Does not } \\
\text { consider the } \\
\text { uncertainties } \\
\text { about DGs' } \\
\text { generation }\end{array}$ & $\begin{array}{l}\text { 6-bus, 14-bus\& } \\
\text { 30-bus IEEE } \\
\text { network }\end{array}$ & $\begin{array}{c}\text { To diminish the } \\
\text { cost losses }\end{array}$ \\
\hline $\begin{array}{c}\text { Hybrid } \\
\text { optimizati } \\
\text { on } \\
\text { algorithms } \\
\text { [79] }\end{array}$ & $\begin{array}{c}\text { Combining } \\
\text { optimal power } \\
\text { flow and genetic } \\
\text { algorithm to find } \\
\text { the best location } \\
\text { and size of } \\
\text { predefined } \\
\text { number of DGs }\end{array}$ & $\begin{array}{c}\text { Fast and high } \\
\text { accuracy }\end{array}$ & $\begin{array}{l}\text { Not suitable } \\
\quad \text { for } \\
\text { simultaneous } \\
\text { installation of } \\
\text { multiple DGs } \\
\text { and for } \\
\text { variable power } \\
\text { load models }\end{array}$ & $\begin{array}{l}\text { 69-bus mesh } \\
\text { network }\end{array}$ & $\begin{array}{l}\text { To minimize } \\
\text { power losses, } \\
\text { improve voltage } \\
\text { profile and } \\
\text { restrict fault } \\
\text { level and } \\
\text { thermal limits }\end{array}$ \\
\hline
\end{tabular}

\section{Protection Coordination}

Since, the integration of Distributed Generation into distribution network cause the bi-directional energy flow, the current levels during the fault inception increase in comparison to the ones without the DGs contribution. Therefore, the already existing, traditional protection schemes may fail to operate efficiently and may cause nuisance and false tripping [83]. Hence, as the efficient coordination of protection devices is necessary for correct operation of distribution network, the renewed relay settings are required after DG installation. The protection coordination issue limited to the downstream network is called a small scale problem while the extension to the upstream network is called a large scale problem [84].

For each incoming DG the settings of primary and back-up relays are required to be changed accordingly. Moreover, the directional element is integrated with overcurrent relays for distinguishing upstream and downstream faults after integration of DGs when power flow becomes bi-directional. Determination of the new relays settings is not an easy task, therefore many different adaptive and non-adaptive algorithms and techniques are used to do so. The new designed protection coordination techniques must be efficient for information monitoring, control and communication and are known to be global protection and control schemes $[85,86]$.

The impact of DG integration on the protection coordination highly depends upon its type, location, and size. Moreover, the characteristics of DG and distribution network are also important factors to be considered while computing new settings for protection devices. It is worth mentioning, that the synchronous DGs contribute to large fault currents, irrespectively of the network configuration, while the inverter based DGs contribute to small fault currents [87].

\subsection{Study Objectives}

The prime objectives of the studies over the protection coordination are:

(1) maintaining the standard Coordination Time Interval (CTI),

(2) updating the Time Multiplier Settings (TMS) and Plug Multiplier Settings (PMS) of relays,

(3) ensuring selectivity, speed, reliability, cost, and simplicity of protection devices.

\subsection{Popular Protection Devices for Distribution Network}

The most popular devices used for protection of low voltage distribution networks are as follows:

(1) fuses,

(2) overcurrent relays:

(a) directional,

(b) inverse time, 
3 of 24

(c) definite time,

(d) instantaneous.

\subsection{Methods of Protection Coordination}

Most of research in the area of protection coordination techniques, have been done for DGs tied to distribution network. Comprehensive summary of all the important methods discussed in different research papers are presented below and their summary is gathered in Table 4 .

Expert system based protection coordination-expert system is a software inspired by the human behavior of solving issues or making rational decisions. Expert systems are used where the traditional data processing is not feasible. Operating on their knowledge database and expertise the expert systems, as a result, also give the reasons on the solution choice [88,89]. Expert systems are used in industrial networks for relay coordination after DG integration. Multiple relay settings were evolved for $22 \mathrm{kV}$ distribution network using expert systems [90], on the basis of load flow, and fault analysis. The general scheme diagram for expert system based protection coordination is shown in Figure 1[90].

The utilization of expert systems for coordination of the protection devices (i.e., relays, fuses and reclosers) in a $33 \mathrm{kV}$ radial system for small scale DGs is suggested in [91]. Protection Device Coordination Expert System (PDCES) software is developed in [92] to help the utility operator evaluate the protection coordination issues. PDCES assesses the causes of mis-coordination, proposes solutions, and ranks the remedies, so that an appropriate action can be taken in accordance to the network characteristics. The potential usage of expert system in protection coordination studies is proposed in $[93,94]$.

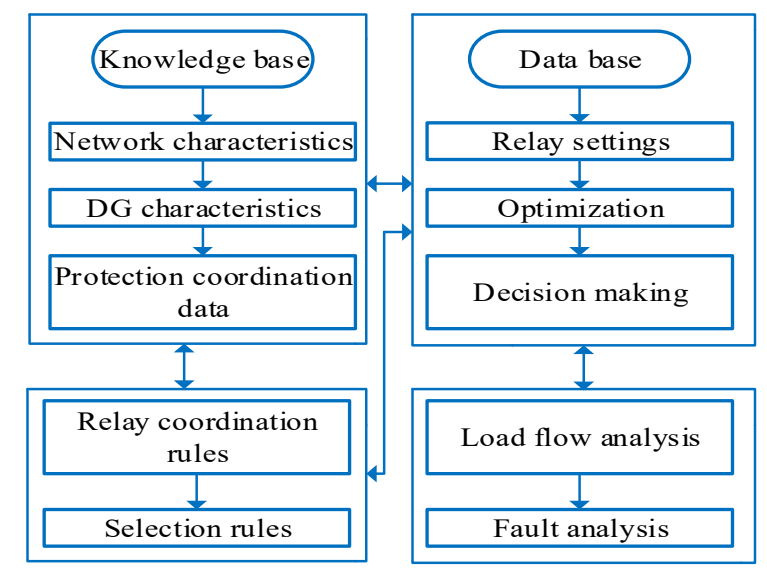

Figure 1. Expert System based protection coordination scheme.

Adaptive protection coordination - an emerging technique in power systems with low DGs penetration. It has ability to automatically process the data when conditions of the network changes with integration of DG. The defined rules and algorithms take the necessary actions accordingly, to achieve the high level of protection coordination in all the abnormal scenarios [95]. The adaptive technique used in [96], checks the relay settings after connection of every new DG on the basis of short circuit currents flowing through the protective devices. Adaptive scheme used in [97], evolves the coordination between protective devices on the basis of coordination time interval margin between their curves. An adaptive scheme suggested in [98] maintains coordination between the fuses in distribution network but all the DGs get disconnected at the instant of fault.

Fault current limiter (FCL) based scheme-integration of DGs into distribution system affects its overcurrent protection schemes and increase the level of fault current closer to the rating of protective devices [99]. The general scheme of FCL based protection coordination is shown in Figure 2 below. 


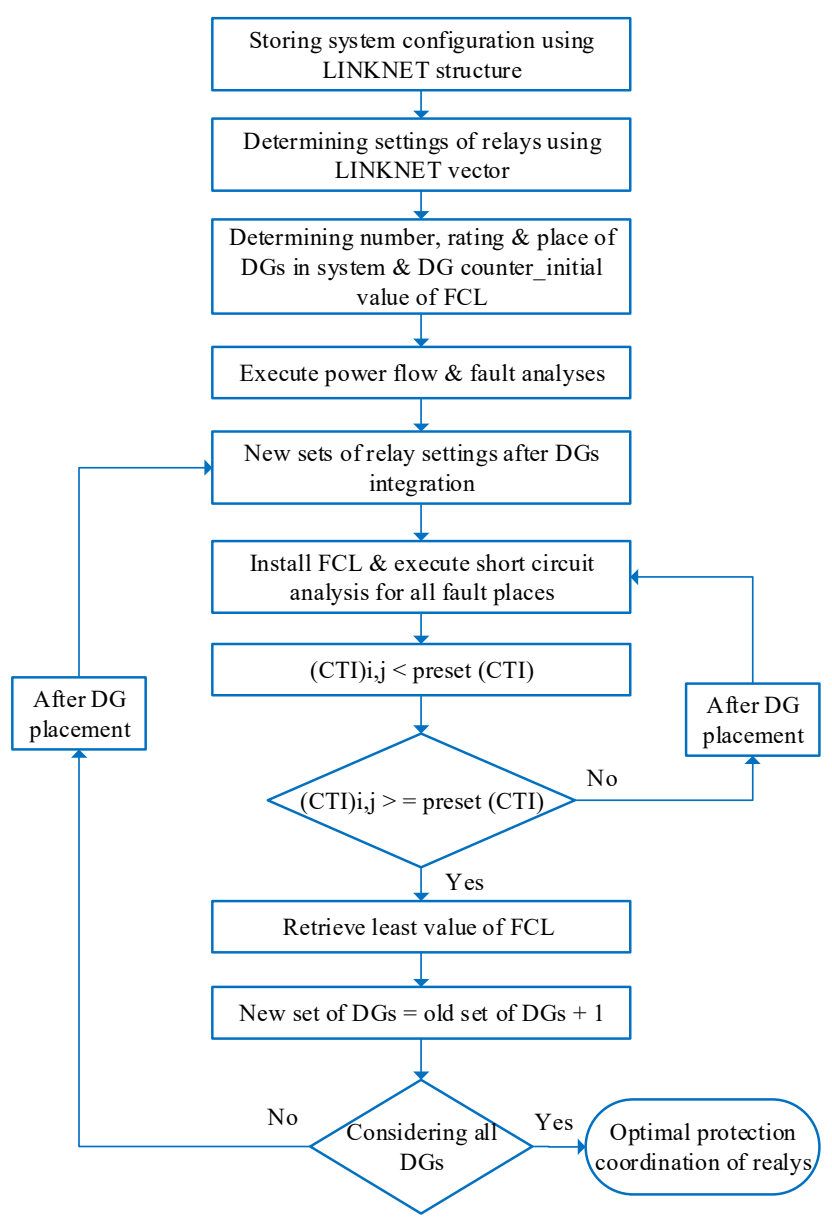

Figure 2. FCL based protection coordination.

One way to overcome the issue of mis-coordination between protection devices after DG integration might be a replacement of the existing scheme for a new one with higher rating, but this would be a costly option. Another way is to limit the value of fault current to the acceptable level so that the existing schemes may operate effectively [100]. The fault current limiters are connected in series with distribution lines to limit the amount of fault current contributions from the DGs. However, fault limiters cause small amount of loading and contribute to the power losses during normal conditions [101]. The LINKNET is type of data structure used to determine the set of random variables.

Directional overcurrent protection coordination-the directional element is added to the conventional overcurrent relays to deal with the bidirectional power flows caused by integration of DGs. This ideas used in [102-104] to isolate internal and external faults in the microgrid. The scheme of operation is based on directional overcurrent relays with additional communication and is relatively expensive. The directional protection scheme with master-slave concept is suggested in [105] to protect the micro-grid system against the external and internal faults. The proposed scheme has communication ability to detect the direction and location of fault. The directional protection scheme using microprocessor based relays proposed in [106] is used to protect the connected grid and also islanded DGs. This proposed scheme does not require communication link and is independent on the level of fault current values and the operation mode of DGs. The limitations of directional overcurrent protection have been identified in [107]. It is pointed out that the unintentional and frequent connection and disconnection of DGs affects the network configuration and the settings of protection devices.

Time-inverse protection coordination - when the fault occurs in a radial utility network, the prime source of fault current is a supply side. There is a huge difference between the magnitudes of 
fault current and load currents so the overcurrent relays are able to distinguish between faulty and normal conditions. However, after the installation of DGs, the margin between the load current and fault current is small and thus the relays cannot efficiently discriminate between them [108]. A method based on voltage-current inverse characteristics is proposed in [109-111] to discriminate between the faulty and normal conditions.

Selection of DGs location and size - the location and size of DG have significant importance in the protection coordination study. The optimal sizing and placement of DG would cause small disturbances in coordination schemes of distribution network. The general scheme of such a method is shown in Figure 3.

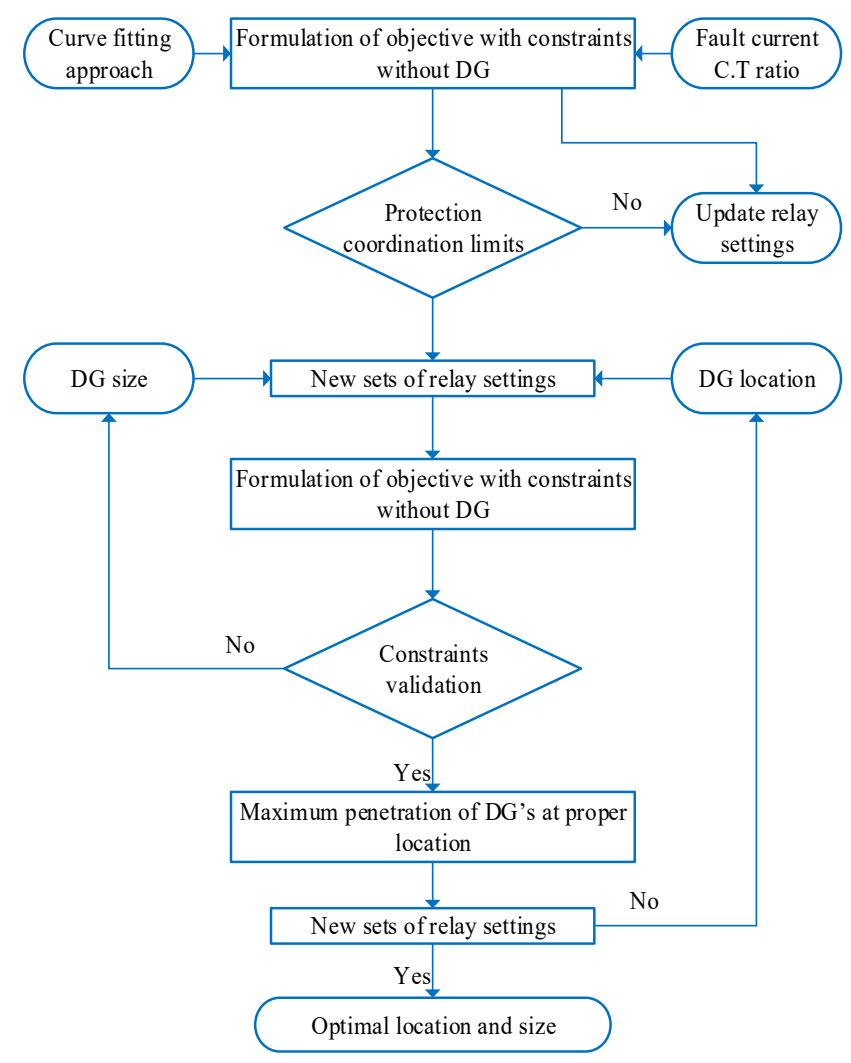

Figure 3. DGs location and sizing based relaying scheme.

The protection coordination scheme discussed in [112] evaluated the effect of size and location of DG on the overcurrent network protection based on fault current in upstream and downstream networks. In [113] the limitations for DGs' penetration are suggested to maintain coordination between conventional protection devices. The effect of size and location of DG on the coordination time interval (CTI) margin of inverse time overcurrent relays is analyzed in [114]. The sensitivity of relays in upstream and downstream network at different DGs location and size is also discussed.

Neuro-fuzzy based protection coordination-with the growing popularity of Artificial Intelligence in the power system applications the protection coordination methods are using fuzzy logic and neural network approaches [115]. Multi-Layer Perceptron Neural Network (MLPNN) based protection coordination scheme is being suggested in [116, 117]. However, this method is not robust due to training and complex structure of neural networks. The protection coordination scheme based on fuzzy logic approach proposed in [118] minimizes the operational time of primary and backup relays and evolutionary algorithm is used to optimize them. In order to add the decision making ability the fuzzy logic is adapted. Three stage neural network based protection coordination scheme is suggested in [119]. The first stage determines the distance to the fault point and the second stage identifies the exact location of fault while the third stage is used to isolate the faulty part from the network. 
Multi-agent protection coordination - a method gaining popularity in protection coordination studies. An agent is an intelligent system which performs the defined autonomous functions in order to achieve desired objectives. The task performed by agents exist in predefined environment and their infrastructure contains communication and interface links [120]. The general scheme of multi-agent protection coordination is shown in Figure 4 [121]. An efficient protection coordination scheme using multi-agents for distribution networks with DGs connected is proposed in [122-124]. A multi-agent based protection coordination scheme proposed in [125] coordinates the overcurrent relays via communication link to enhance the efficiency of protection coordination and to decrease the operating time of relays. The multi-agent protection scheme proposed in [126] divides the system into various protection zones. This protection scheme has distributed control but makes coordinated decisions. Then, a peer-to-peer multi-agent protection coordination is suggested in [127]. A multi-agent approach is also used in cases where the operational timing of relays is longer due to small fault currents in the network. The inverter based DGs connected to low voltage network contribute small amount of current to the fault points [128,129]. Also, a communication based protection coordination scheme using synchro-phasors is used in [130].

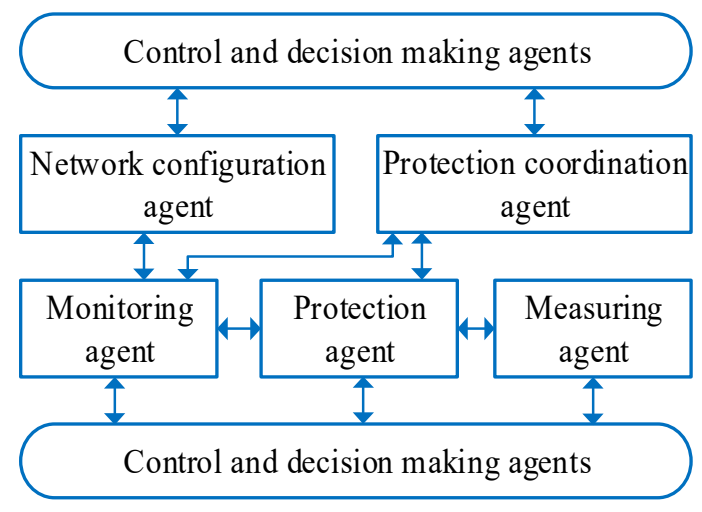

Figure 4. Multi-agent relaying scheme.

Table 4. Summary of Methods for Protection Coordination of DGs.

\begin{tabular}{|c|c|c|c|c|c|}
\hline Technique & Main Features & Merits & Demerits & $\begin{array}{c}\text { Network } \\
\text { Configurati } \\
\text { on }\end{array}$ & Objectives \\
\hline $\begin{array}{c}\text { Directional } \\
\text { overcurrent } \\
\text { element } \\
\text { [131] }\end{array}$ & $\begin{array}{l}\text { Discriminating } \\
\text { upstream and } \\
\text { downstream } \\
\text { currents. }\end{array}$ & $\begin{array}{c}\text { Significant } \\
\text { discrimination } \\
\text { between fault and } \\
\text { load current }\end{array}$ & $\begin{array}{l}\text { Problem with } \\
\text { phase and } \\
\text { ground } \\
\text { directional } \\
\text { elements }\end{array}$ & $\begin{array}{c}4 \text { bus radial } \\
\text { network }\end{array}$ & $\begin{array}{c}\text { To avoid false } \\
\text { tripping and to } \\
\text { halt system at } \\
\text { increased fault } \\
\text { level than } \\
\text { predefined value }\end{array}$ \\
\hline $\begin{array}{l}\text { Adaptive } \\
\text { inverse-time } \\
\text { overcurrent } \\
\text { protection } \\
\text { [132] }\end{array}$ & $\begin{array}{c}\text { Clearing } \\
\text { overcurrent, } \\
\text { under-voltage and } \\
\text { symmetrical faults } \\
\text { without considering } \\
\text { upper and lower } \\
\text { operating time limits } \\
\text { while maintaining } \\
\text { coordination time }\end{array}$ & $\begin{array}{l}\text { Higher selectivity, } \\
\text { smart, robust, } \\
\text { adaptive and } \\
\text { reliable }\end{array}$ & $\begin{array}{c}\text { Does not } \\
\text { perform well } \\
\text { during changing } \\
\text { conditions of } \\
\text { network }\end{array}$ & $\begin{array}{c}13 \text { bus IEEE } \\
\text { network }\end{array}$ & $\begin{array}{l}\text { To calculate new } \\
\text { PMS for relays } \\
\text { by using } \\
\text { information of } \\
\text { overcurrent, zero } \\
\text { sequence fault } \\
\text { current and } \\
\text { voltage drop in } \\
\text { network }\end{array}$ \\
\hline $\begin{array}{c}\text { Optimal } \\
\text { location and } \\
\text { sizing of DG } \\
\text { [133-136] }\end{array}$ & $\begin{array}{l}\text { Sizing and placing } \\
\text { DGs so that have } \\
\text { low effect on } \\
\text { protection scheme of } \\
\text { network }\end{array}$ & $\begin{array}{l}\text { Economical results } \\
\text { in least outage } \\
\text { duration, does not } \\
\text { require network } \\
\text { modifications }\end{array}$ & $\begin{array}{l}\text { Not efficient } \\
\text { with high } \\
\text { penetration of } \\
\text { DGs }\end{array}$ & $\begin{array}{l}\text { RBTS Bus } 2 \\
\text { system/15 } \\
\text { bus IEEE } \\
\text { system }\end{array}$ & $\begin{array}{l}\text { To reduce total } \\
\text { outage time and } \\
\text { energy costs }\end{array}$ \\
\hline $\begin{array}{c}\text { Time } \\
\text { coordination } \\
\text { method } \\
\text { [137] }\end{array}$ & $\begin{array}{l}\text { Achieving most of } \\
\text { optimal protection } \\
\text { settings with least } \\
\text { disturbance and }\end{array}$ & $\begin{array}{c}\text { Generates various } \\
\text { possible solutions } \\
\text { (neighbors) }\end{array}$ & $\begin{array}{l}\text { New relay } \\
\text { settings are } \\
\text { required to be } \\
\text { generated each }\end{array}$ & $\begin{array}{l}\text { Ring-fed } \\
\text { distribution } \\
\text { system }\end{array}$ & $\begin{array}{l}\text { To achieve zero } \\
\text { supply failure } \\
\text { rate and } \\
\text { interruption }\end{array}$ \\
\hline
\end{tabular}




\begin{tabular}{|c|c|c|c|c|c|}
\hline & failure timings & & $\begin{array}{l}\text { time with new } \\
\text { DGs } \\
\end{array}$ & & frequency \\
\hline $\begin{array}{c}\text { Solid state } \\
\text { unidirectional } \\
\text { fault current } \\
\text { limiter } \\
\text { (SSUFCL) } \\
\text { [138] }\end{array}$ & $\begin{array}{l}\text { Restricting fault } \\
\text { currents within } \\
\text { defined zones used } \\
\text { as an interface } \\
\text { between upstream } \\
\text { and downstream } \\
\text { networks. }\end{array}$ & $\begin{array}{l}\text { Suitable for DGs } \\
\text { with storage } \\
\text { system and } \\
\text { converter } \\
\text { technology }\end{array}$ & $\begin{array}{l}\text { Unable to } \\
\text { provide } \\
\text { discrimination } \\
\text { between } \\
\text { upstream and } \\
\text { downstream } \\
\text { relays close to } \\
\text { DGs }\end{array}$ & $\begin{array}{l}7 \text { bus test } \\
\text { system }\end{array}$ & $\begin{array}{l}\text { To optimize the } \\
\text { time and current } \\
\text { settings of } \\
\text { overcurrent } \\
\text { relays and } \\
\text { characteristics of } \\
\text { SSUFCL }\end{array}$ \\
\hline $\begin{array}{l}\text { Adaptive } \\
\text { differential } \\
\text { current } \\
\text { protection } \\
\text { [139] }\end{array}$ & $\begin{array}{l}\text { Changing values of } \\
\text { fault level and } \\
\text { network } \\
\text { configuration are } \\
\text { required for relay } \\
\text { coordination in both } \\
\text { grid-connected and } \\
\text { islanded mode DGs }\end{array}$ & $\begin{array}{l}\text { Applicable to MV } \\
\text { network with } \\
\text { inverter based DG } \\
\text { technology }\end{array}$ & $\begin{array}{c}\text { Cannot be } \\
\text { applied to } \\
\text { synchronous } \\
\text { DGs }\end{array}$ & $\begin{array}{c}3 \text { bus radial } \\
\text { network }\end{array}$ & $\begin{array}{l}\text { To avoid false } \\
\text { fault detection } \\
\text { based on } \\
\text { differential } \\
\text { current with } \\
\text { least frequency } \\
\text { deviations } \\
\text { between supply } \\
\text { and load } \\
\end{array}$ \\
\hline $\begin{array}{l}\text { Multi-agent } \\
\text { adaptive } \\
\text { protection } \\
\text { coordination } \\
{[140,141]}\end{array}$ & $\begin{array}{l}\text { Deciding settings of } \\
\text { digital overcurrent } \\
\text { relays on the basis of } \\
\text { condition of agents } \\
\text { and communication } \\
\text { between them }\end{array}$ & $\begin{array}{l}\text { Used for complex } \\
\text { networks with } \\
\text { frequent changing } \\
\text { dynamics }\end{array}$ & $\begin{array}{l}\text { Continuous } \\
\text { communication } \\
\text { between } \\
\text { overcurrent } \\
\text { relay agents, } \\
\text { feeder agents } \\
\text { and display } \\
\text { agents are } \\
\text { required } \\
\end{array}$ & $\begin{array}{c}2 \text { bus radial } \\
\text { network } 4 \\
\text { bus radial } \\
\text { network }\end{array}$ & $\begin{array}{l}\text { To determine } \\
\text { relays settings } \\
\text { through learning } \\
\text { algorithm and } \\
\text { communicate } \\
\text { with its } \\
\text { neighboring } \\
\text { agents }\end{array}$ \\
\hline $\begin{array}{c}\text { Directional } \\
\text { protection } \\
\text { with fault } \\
\text { current limiter } \\
\text { (FCL) } \\
\text { [142] }\end{array}$ & $\begin{array}{l}\text { Determining settings } \\
\text { of FCL through } \\
\text { algorithm that limits } \\
\text { the fault current }\end{array}$ & $\begin{array}{c}\text { Eliminates } \\
\text { complexity in } \\
\text { control strategies, } \\
\text { ensures reliability } \\
\text { and safety of } \\
\text { network at the } \\
\text { lowest costs }\end{array}$ & $\begin{array}{l}\text { Connection and } \\
\text { disconnection of } \\
\text { DGs may affect } \\
\text { the values of } \\
\text { FCL and relay } \\
\text { settings }\end{array}$ & $\begin{array}{c}30 \text { bus IEEE } \\
\text { system }\end{array}$ & $\begin{array}{l}\text { To minimize the } \\
\text { cost function at } \\
\text { zero values of } \\
\text { FCLs }\end{array}$ \\
\hline $\begin{array}{c}\text { Voltage sag } \\
\text { coordination } \\
\text { technique } \\
{[143,144]}\end{array}$ & $\begin{array}{l}\text { Disconnecting DG } \\
\text { from the system } \\
\text { when voltage falls } \\
\text { below } 0.5 \text { p.u in less } \\
\text { than six cycles and } \\
\text { coordinating relays } \\
\text { on the basis of } \\
\text { specific energy as } \\
\text { the function of time. }\end{array}$ & $\begin{array}{l}\text { Can be applied to } \\
\text { both synchronous } \\
\text { and static DGs } \\
\text { with different } \\
\text { ratings }\end{array}$ & $\begin{array}{l}\text { More laborious, } \\
\text { limited to small } \\
\text { DGs }\end{array}$ & $\begin{array}{c}1 \text { bus radial } \\
\text { network }\end{array}$ & $\begin{array}{l}\text { To maintain } \\
\text { standard } \\
\text { coordination } \\
\text { time margin }\end{array}$ \\
\hline $\begin{array}{c}\text { Adaptive } \\
\text { protection } \\
\text { coordination } \\
{[145]}\end{array}$ & $\begin{array}{l}\text { Calculating time dial } \\
\text { and plug multiplier } \\
\text { settings of relays on } \\
\text { the basis of varying } \\
\text { parameters/configur } \\
\text { ation of the network }\end{array}$ & $\begin{array}{l}\text { Extremely flexible } \\
\text { to maintain the } \\
\text { coordination } \\
\text { among } \\
\text { overcurrent relays } \\
\text { and distance } \\
\text { relays }\end{array}$ & $\begin{array}{l}\text { Communication } \\
\text { and numerical } \\
\text { relays are } \\
\text { required for } \\
\text { obtaining best } \\
\text { settings }\end{array}$ & $\begin{array}{l}8 \text { bus test } \\
\text { system } \\
\text { and14 bus } \\
\text { IEEE } \\
\text { network }\end{array}$ & $\begin{array}{c}\text { To avoid } \\
\text { nuisance } \\
\text { tripping of } \\
\text { overcurrent and } \\
\text { distance relays at } \\
\text { distribution and } \\
\text { transmission } \\
\text { levels } \\
\text { respectively } \\
\end{array}$ \\
\hline $\begin{array}{c}\text { Directional } \\
\text { inverse time } \\
\text { overcurrent } \\
\text { protection } \\
\text { [146] }\end{array}$ & $\begin{array}{l}\text { Estimating the } \\
\text { direction of fault } \\
\text { current on the basis } \\
\text { of its angle with } \\
\text { polarizing voltage in } \\
\text { both forward and } \\
\text { reverse directions } \\
\text { for relay settings }\end{array}$ & $\begin{array}{l}\text { Used for complex } \\
\text { power networks } \\
\text { and for systems } \\
\text { with changing } \\
\text { dynamics }\end{array}$ & $\begin{array}{l}\text { Additional } \\
\text { nonlinear } \\
\text { multi-variable } \\
\text { function is used } \\
\text { which only } \\
\text { works for } \\
\text { continuous first } \\
\text { derivatives of } \\
\text { the system } \\
\end{array}$ & $\begin{array}{c}30 \text { bus IEEE } \\
\text { network }\end{array}$ & $\begin{array}{l}\text { To diminish the } \\
\text { coordination } \\
\text { delay between } \\
\text { relays while } \\
\text { maintaining } \\
\text { protection } \\
\text { coordination } \\
\text { limits }\end{array}$ \\
\hline $\begin{array}{c}\text { Centralized } \\
\text { adaptive } \\
\text { scheme } \\
\end{array}$ & $\begin{array}{c}\text { Optimizing the relay } \\
\text { setting on the basis } \\
\text { of network }\end{array}$ & $\begin{array}{c}\text { Automatic online } \\
\text { coordination, } \\
\text { desired selectivity }\end{array}$ & $\begin{array}{c}\text { For every } \\
\text { change in the } \\
\text { network }\end{array}$ & $\begin{array}{c}6 \text { bus } \\
\text { interconnect } \\
\text { ed network }\end{array}$ & $\begin{array}{c}\text { To minimize the } \\
\text { primary and } \\
\text { backup }\end{array}$ \\
\hline
\end{tabular}




\begin{tabular}{|c|c|c|c|c|c|}
\hline [147] & $\begin{array}{l}\text { conditions, using } \\
\text { SCADA server that } \\
\text { retrieves the } \\
\text { network data and } \\
\text { perform load flow, } \\
\text { contingency analysis } \\
\text { and sensitivity } \\
\text { analysis. }\end{array}$ & and sensitivity & $\begin{array}{l}\text { conditions, the } \\
\text { process is } \\
\text { repeated }\end{array}$ & & $\begin{array}{l}\text { operation time of } \\
\text { relays while } \\
\text { retaining desired } \\
\text { selectivity }\end{array}$ \\
\hline $\begin{array}{c}\text { Neuro-fuzzy } \\
\text { protection } \\
{[148]}\end{array}$ & $\begin{array}{l}\text { Deciding the } \\
\text { optimal settings of } \\
\text { IDMT relays based } \\
\text { on the status of DG } \\
\text { and network } \\
\text { conditions. With } \\
\text { Fuzzy inference The } \\
\text { results are } \\
\text { optimized through } \\
\text { neural network with } \\
\text { voltage and current } \\
\text { phasor based DFT } \\
\text { algorithm }\end{array}$ & $\begin{array}{l}\text { Applicable to } \\
\text { networks with } \\
\text { changing } \\
\text { parameters and } \\
\text { with multiple } \\
\text { DGs' integration. } \\
\text { Better } \\
\text { performance in } \\
\text { terms of speed and } \\
\text { efficiency }\end{array}$ & $\begin{array}{l}\text { Complexity is } \\
\text { high, } \\
\text { computational } \\
\text { times are large }\end{array}$ & $\begin{array}{c}34 \text { bus IEEE } \\
\text { system }\end{array}$ & $\begin{array}{l}\text { To ensure } \\
\text { desired } \\
\text { coordination } \\
\text { time in closed } \\
\text { loop system }\end{array}$ \\
\hline $\begin{array}{l}\text { Expert System } \\
\text { protection } \\
\text { coordination } \\
{[90,149]}\end{array}$ & $\begin{array}{l}\text { Using expert system } \\
\text { as decision tool to } \\
\text { investigate the effect } \\
\text { of DG integration } \\
\text { and proposes } \\
\text { protection } \\
\text { coordination } \\
\text { settings for relays }\end{array}$ & $\begin{array}{l}\text { Simple, robust and } \\
\text { suitable for system } \\
\text { with multiple } \\
\text { coordination } \\
\text { settings }\end{array}$ & $\begin{array}{l}\text { With changing } \\
\text { configuration of } \\
\text { network, } \\
\text { computation } \\
\text { processing time } \\
\text { is large }\end{array}$ & $\begin{array}{l}22-\mathrm{kV} \text { test } \\
\text { system }\end{array}$ & $\begin{array}{l}\text { To identify the } \\
\text { maximum and } \\
\text { minimum fault } \\
\text { currents in the } \\
\text { protection zones }\end{array}$ \\
\hline $\begin{array}{l}\text { Communicati } \\
\text { on assisted } \\
\text { digital relay } \\
\text { scheme } \\
\text { [150] }\end{array}$ & $\begin{array}{c}\text { Providing } \\
\text { under-voltage and } \\
\text { overcurrent } \\
\text { protection with } \\
\text { grouped relays } \\
\text { based on short } \\
\text { circuit capacity of } \\
\text { system }\end{array}$ & $\begin{array}{l}\text { Used for high } \\
\text { impedance faults } \\
\text { and integration of } \\
\text { multiple DGs }\end{array}$ & $\begin{array}{c}\text { Complete } \\
\text { knowledge of } \\
\text { entire } \\
\text { configuration } \\
\text { and parameters } \\
\text { of network is } \\
\text { difficult and } \\
\text { security of } \\
\text { communication } \\
\text { link is necessary. }\end{array}$ & $\begin{array}{l}6 \text { busand } 13 \\
\text { bus loop } \\
\text { network }\end{array}$ & $\begin{array}{l}\text { To optimize } \\
\text { location and } \\
\text { number of relays } \\
\text { according to } \\
\text { network } \\
\text { configuration } \\
\text { and } \\
\text { characteristics of } \\
\text { DGs }\end{array}$ \\
\hline $\begin{array}{c}\text { Coordinated } \\
\text { backup } \\
\text { protection } \\
{[151]}\end{array}$ & $\begin{array}{l}\text { Analyzing different } \\
\text { faults based on } \\
\text { coordinated } \\
\text { substation which } \\
\text { works on differential } \\
\text { principle and acts as } \\
\text { backup for master } \\
\text { station } \\
\end{array}$ & $\begin{array}{c}\text { Suitable for } \\
\text { network with } \\
\text { varying power } \\
\text { flows, does not } \\
\text { require complete } \\
\text { information about } \\
\text { system }\end{array}$ & $\begin{array}{l}\text { Communication } \\
\text { protocol } \\
\text { between master } \\
\text { station and } \\
\text { coordinated } \\
\text { station is } \\
\text { required to be } \\
\text { secure }\end{array}$ & $\begin{array}{c}14 \text { bus IEEE } \\
\text { system }\end{array}$ & $\begin{array}{l}\text { To minimize the } \\
\text { probability of } \\
\text { protection } \\
\text { failure }\end{array}$ \\
\hline
\end{tabular}

\section{Future Scope and Recommendations}

In this article, authors have identified the possible future scope and challenges for protection coordination schemes and DG location and sizing methods.

\subsection{DG Location and Sizing Methods}

(1) The optimal sizing and placement of DGs, proper placement of capacitor banks and the network reconfiguration are the three best options for minimizing the power losses in distribution systems. The coordination planning of all these three options results in economical results. Therefore, during the network reconfiguration, proper placement and sizing of DGs, capacitor banks and protection devices should be carried out simultaneously.

(2) New model of DGs placement and sizing using information of voltage sag distribution network with objective of minimizing losses is aim of future research. 
(3) The optimizations methods used for optimal sizing and location of DGs are based on trial and error methods. In order to improve their performance and efficacy, their objective functions should be evaluated adaptively and automatically.

(4) The stability of distribution system should be considered after large penetrations of DGs because the system becomes active then. Moreover, the energy management strategy during transient operation of network should be designed with available distributed generation.

(5) The effects of new DG installation on the characteristics of existing DGs in distribution network should be analyzed. The dynamic model for proper placement and sizing of DGs will be an effective solution.

(6) With the installation of DGs, not only voltage of network is rised up but also the power quality is significantly being changed. With the online monitoring and control of distribution network, the capacity of network to accommodate new DGs can be determined, the new relay settings can be deduced and the cost of integrating DGs can be calculated. The Online Management System (OMS) integrated with model of DGs placement and sizing is the work of future research.

(7) The different parameters of objective functions of DGs placement and sizing algorithms are uncertain such as; output power of distributed sources, future power demand, fuel costs, market trends, charging and discharging characteristics of electric vehicles, future investments, availability of fuel reserves, etc. Therefore, deterministic and evolutionary algorithms should be used to deal with such uncertainties.

\subsection{Schemes of Protection Coordination}

(1) High penetration of DGs at distribution levels affects the reach of upstream distance relays at transmission level. Therefore, during installation of multiple DGs, not only relays settings of downstream distribution system but also relays at upstream transmission level should be considered.

(2) Since the relays are coordinated while considering the lower limit of CTI and neglecting its upper limit. Thus, in case of low fault current contributions from DGs, the operation of backup overcurrent protection is delayed. Therefore, in order to achieve optimal operation of overcurrent relays during such scenarios, time inverse current relay characteristics should be applied in relay coordination schemes.

(3) Installation of DGs influences the configuration of distribution network and hence directional relays are installed to distinguish between the upstream and downstream fault currents. In such situations, the selection of relays settings for backup protection becomes more complicated and thus simple curve fitting techniques are ineffective to do so. Therefore, modern communication based techniques are required to solve such issue for highly complex systems.

(4) Integration of photo-voltaic systems into power system makes the protection schemes more complicated due to their small fault current contribution. Under such conditions, the accuracy and robustness of protection schemes is a challenging task. Using voltage sag characteristics of system, protection schemes for distribution with PV system can be designed.

(5) With high penetration of DGs, the communication based coordination schemes with distributed adaptive techniques become inactive. In future coordination studies, this issue should be considered.

(6) In [142], Author used the information of voltage sag for protection coordination of relays and in [145], Author coordinated the relays using fault current angle. Since, with high penetration of DGs into distribution network, not only the magnitude of voltage is affected but also its angle, during the steady state as well as during the transient conditions. Therefore, a new protection scheme can be designed on the basis of both parameters of voltage sag (magnitude+angle), which is ongoing research of Authors

(7) Due to interconnection of highly loaded distribution systems and the installations of DGs, the short circuit capacity of network changes adversely and causes sympathetic tripping of relays. 
Such issue should be considered while integrating DGs into distribution network during steady state and dynamic conditions of system.

\section{Conclusions}

This article presented the detailed review of protection coordination schemes and placement and sizing methods of DGs in distribution networks. The integration of DG into distribution system creates many protection coordination issues. The sensitivity of these issues highly depends upon the place and rating of incoming DG. Therefore, different methods and optimization techniques for optimal placement and sizing of DG were discussed. The most common objective among all the techniques was the reduction of losses and enhancement of voltage profile. The most frequently used methods for proper placement and sizing of DG are Genetic Algorithm (GA) and different practical heuristic algorithms.

After the DGs are optimally sized and placed then issues arise with bidirectional power flows in distribution networks. The existing protection schemes fail to clear the faults correctly. This article addressed various protection coordination methods. The application of different protection schemes were based on the characteristics of network and installed DGs. The protection coordination problems were formulated as linear and non-linear problems and were then evolved by different optimization methods to determine their optimal protection settings. All the discussed protection schemes were based on restraining the adverse effects of DGs and updating their protection characteristics.

This article also discussed possible research gaps, applications and limitations of different protection coordination schemes and DG sizing and placement methods.

Author Contributions: L.S. was responsible for conceptualization and methodology, S.K. performed analysis, research and original draft preparation, Z.L. performed supervision, review and editing.

Funding: This research was partially funded by Wroclaw University of Science and Technology, grant number 0401/0037/17.

Acknowledgments: Authors are very much thankful to Wroclaw University of Science and Technology, Poland for providing peaceful and stimulating environment for conducting this research work. The first author is very much grateful to Nisar Ahmed Siddiqui, Vice Chancellor of Sukkur IBA University for always motivating and appreciating the research work conducted.

Conflicts of Interest: The authors declare no conflict of interest.

\section{References}

1. Howell, S.; Rezgui, Y.; Hippolyte, J.L.; Jayan, B.; Li, H. Towards the next generation of smart grids: Semantic and holonic multi-agent management of distributed energy resources. Renew. Sustain. EnergyRev. 2017, 77, 193-214.

2. Balamurugan, K.; Srinivasan, D.; Reindl, T. Impact of Distributed Generation on Power Distribution Systems. EnergyProcedia2012, 25, 93-100.

3. Juan, Y.; Ming, S.; Bo, D. Research about Impact of DGs in Distribution Network. IEEE Ind. Appl. Mag.2003, $1-6$.

4. Ogunjuyigbe, A.S.O.; Ayodele, T.R.; Akinola, O.O. Impact of distributed generators on the power loss and voltage profile of subtransmission network. J. Electr. Syst. Inf. Technol.2015, 3, 94-107.

5. Hlatshwayo, M.; Chowdhury, S.; Chowdhury, S.P.; Awodele, K.O. Impacts of DO Penetration in the Reliability of Distribution Systems. In Proceedings of the International Conference on Power System Technology, Hangzhou, China, 24-28 October2010.

6. Muhammad Yousaf, Tahir Mahmood, "Protection coordination for a distribution system in the presence of distributed generation", Turkish Journal of Electrical Engineering \& Computer Sciences, 2017, 25, 408-421.

7. Sharaf, H.M.; Zeineldin, H.H.; Ibrahim, D.K.; Zahab, E. A proposed coordination strategy for meshed distribution systems with DG considering user-defined characteristics of directional inverse time overcurrent relays. Int. J.Electr. Power Energy Syst. 2015, 65, 49-58. 
8. Haron, A.R.; Mohamed, A.; Shareef, H. Coordination of Overcurrent Directional and Differential Relays for the Protection of Microgrid System. Procedia Technol. 2013, 11, 366-373.

9. Georgilakis, P.S.; Hatziargyriou, N.D. Optimal distributed generation placement in power distribution networks: Models methods and future research. IEEE Trans. Power Syst. 2013, 28, 3420-3428.

10. Shanna, P.; Tandon, A. Techniques for Optimal Placement of DG in Radial Distribution System: A Review. In Proceeding of the International Conference on Communication, Control and Intelligent Systems, Mathura, India, 7-8 November2015.

11. El-Khattam, W.; Salama, M. Distributed generation technologies definitions and benefits. Electr. Power Syst. Res. 2004, 71, 119-128.

12. Rau, N.S.; Wan, Y.-H. Optimum location of resources in distributed planning. IEEETrans. PowerSyst. 1994, 9, 2014-2020.

13. Vovos, P.; Bialek, J. Direct incorporation of fault level constraints in optimal power flow as a tool for network capacity analysis. IEEETrans. PowerSyst. 2005, 20, 2125-2134.

14. Keane, A.; O'Malley, M. Optimal allocation of embedded generation on distribution networks. IEEETrans. PowerSyst. 2005, 20, 1640-1646.

15. Keane, A.; O'Malley, M. Optimal utilization of distribution networks for energy harvesting. IEEETrans. PowerSyst. 2007, 22, 467-475.

16. Vovos, P.N.; Harrison, G.P.; Wallace, A.R.; Bialek, J.W. Optimal power flow as a tool for fault level-constrained network capacity analysis. IEEETrans. PowerSyst. 2005, 20, 734-741.

17. AlHajri, M.F.; AlRashidi, M.R.; El-Hawary, M.E. Improved sequential quadratic programming approach for optimal distribution generation deployments via stability and sensitivity analyses. Electr. PowerCompon. Syst. 2010, 38, 1595-1614.

18. M. F. AlHajri, M. R. AlRashidi, and M. E. El-Hawary, Improved Sequential Quadratic Programming approach for optimal Distribution Generation sizing in distribution networks, Proceedings of the 23rd Canadian Conference on Electrical and Computer Engineering, 2010, doi: 10.1109/CCECE.2010.5575191

19. Zhu, D.; Broadwater, R.P.; Tam, K.-S.; Seguin, R.; Asgeirsson, H. Impact of DG placement on reliability and efficiency with time-varying loads. IEEETrans. PowerSyst. 2006, 21, 419-427.

20. Mahmoud Pesaran H. A., Abdullah Asuhaimi Bin Mohd Zin, Azhar Bin Khairuddin \& Omid Shariati, “Optimal Sizing and Siting of Distributed Generators by Exhaustive Search", Distributed Generation \& Alternative Energy Journal, 2015, 30:3, 29-56, DOI: 10.1080/21563306.2015.11461421

21. M. Abdel-Akher, A. A. Ali, A. M. Eid, H. El-Kishky, "Optimal size and location of distributed generation unit for voltage stability enhancement", Proc. IEEE ECCE,2011, pp. 104-108, doi: 10.1109/ECCE.2011.6063755

22. Khan, H.; Choudhry, M.A. Implementation of distributed generation (IDG) algorithm for performance enhancement of distribution feeder under extreme load growth. Int. J. Electr. PowerEnergySyst. 2010, 32, 985-997.

23. Ochoa, L.F.; Padilha-Feltrin, A.; Harrison, G.P. Evaluating distributed time-varying generation through a multiobjective index. IEEETrans. PowerDeliv. 2008, 23, 1132-1138.

24. Jabr, R.A.; Pal, B.C. Ordinal optimisation approach for locating and sizing of distributed generation. IETGener. Transm. Distrib. 2009, 3, 713-723.

25. Khalesi, N.; Rezaei, N.; Haghifam, M.-R. DG allocation with application of dynamic programming for loss reduction and reliability improvement. Int. J. Electr. PowerEnergySyst. 2010, 33, 288-295.

26. Ochoa, L.F.; Dent, C.J.; Harrison, G.P. Distribution network capacity assessment: Variable DG and active networks. IEEETrans. PowerSyst. 2010, 25, 87-95.

27. Dent, C.J.; Ochoa, L.F.; Harrison, G.P. Network distributed generation capacity analysis using OPF with voltage step constraints. IEEETrans. PowerSyst. 2010, 25, 296-304.

28. Ochoa, L.F.; Harrison, G.P. Minimizing energy losses: Optimal accommodation and smart operation of renewable distributed generation. IEEETrans. PowerSyst. 2011, 26, 198-205.

29. Atwa, Y.M.; El-Saadany, E.F. Probabilistic approach for optimal allocation of wind-based distributed generation in distribution systems. IETRenew. PowerGener. 2011, 5, 79-88.

30. Harrison, G.; Wallace, A. Optimal power flow evaluation of distribution network capacity for the connection of distributed generation. Proc. Inst. Electr. Eng. Gener. Transm. Distrib. 2005, 152, 115-122. 
31. Al Abri, R.S.; El-Saadany, E.F.; Atwa, Y.M. Optimal placement and sizing method to improve the voltage stability margin in a distribution system using distributed generation. IEEE Trans. Power Syst. 2013, 28, 326-334.

32. Kumar, A.; Gao, W. Optimal distributed generation location using mixed integer non-linear programming in hybrid electricity markets. IETGener. Transm. Distrib. 2010, 4, 281-298.

33. Porkar, S.; Poure, P.; Abbaspour-Tehrani-Fard, A.; Saadate, S. Optimal allocation of distributed generation using a two-stage multi-objective mixed-integer-nonlinear programming. Eur. Trans. Electr. Power2011, 21, 1072-1087.

34. El-Khattam, W.; Hegazy, Y.G.; Salama, M.M.A. An integrated distributed generation optimization model for distribution system planning. IEEETrans. PowerSyst. 2005, 20, 1158-1165.

35. Singh, D.; Mirsa, R.K.; Singh, D. Effect of Load Models in Distributed Generation Planning. IEEETrans. PowerSyst. 2007, 22, 2204-2212.

36. Zeineldin, H.H.; Mohamed, Y.; Khadkikar, V.; Pandi, V.R.A protection coordination index for evaluating distributed generation impacts on protection for meshed distribution systems. IEEE Trans. Smart Grid 2013, 4, 1523-1532.

37. Kotamarty, S.; Khushalani, S.; Schulz, N. Impact of Distributed Generation on Distribution Contingency Analysis. Electr. Power Syst. Res. 2008, 78, 1537-1545.

38. Saleh KAZeineldinHHEl-Saadany, E.F. Optimal protection coordination for microgrids considering N-1 contingency. IEEE Trans. Ind. Inf. 2017, 13, 2270-2278.

39. Willis, H.L. Analytical methods and rules of thumb for modeling DG-distribution interaction. In Proceedings of the IEEE Power Engineering Society Summer Meeting, Seattle, WA, USA, 16-20July 2000; pp. 1643-1644.

40. Lee, S.-H.; Park, J.-W. Selection of optimal location and size of multiple distributed generations by using Kalman filter algorithm. IEEETrans. PowerSyst. 2009, 24, 1393-1400.

41. Gözel, T.; Hocaoglu, M.H. An analytical method for the sizing and siting of distributed generators in radial systems. Electr. Power Syst. Res. 2009, 79, 912-918.

42. Hung, D.Q.; Mithulananthan, N.; Bansal, R.C. Analytical Expres-sions for DG Allocation in Primary Distribution Networks. IEEETrans. EnergyConvers. 2010, 25, 814-820.

43. Hung, D.Q.; Mithulananthan, N. Multiple Distributed Generators Placement in Primary Distribution Networks for Loss Reduction. IEEETrans. Ind. Electron. 2013, 60, 1700-1708.

44. Acharya, N.; Mahat, P.; Mithulananthan, N. An analytical Approach for DG Allocation in Primary Distribution Network. J.Electr. PowerEnergySyst. 2006, 28, 669-678.

45. Costa, P.M.; Matos, M.A. Avoided Losses on LV Networksas a Result of Microgeneration. Electr. Power Syst. Res. 2009, 79, 629-634.

46. Man, K.F.; Tang, K.S.; Kwong, S. Genetic algorithms: Concepts and applications. IEEETrans. Ind. Electron. 1996, 43, 519-534.

47. Borges, C.L.T.; Falcão, D.M. Optimal distributed generation allocation for reliability, losses, and voltage improvement. Int. J.Electr. Power Energy Syst. 2006, 28, 413-420.

48. Singh, R.K.; Goswami, S.K. Optimum siting and sizing of distributed generations in radial and networked systems. Electr. PowerCompon. Syst. 2009, 37, 127-145.

49. Singh, D.; Singh, D.; Verma, K.-S. Multiobjective optimization for DG planning with load models. IEEETrans. PowerSyst. 2009, 24, 427-436.

50. Singh, R.K.; Goswami, S.K. Optimum allocation of distributed generations based on nodal pricing for profit, loss reduction, and voltage improvement including voltage rise issue. Int. J. Electr. PowerEnergySyst. 2010, 32, 637-644.

51. Caprinelli, G.; Celli, G.; Pilo, F.; Russo, A. Embedded generation planning under uncertainty including power quality issues. Eur. Trans. Electr. Power2003, 13, 381-389.

52. Kim, K.-H.; Lee, Y.-J.; Rhee, S.-B.; Lee, S.-K.; You, S.-K. Dispersed generator placement using fuzzy-GA in distribution systems. In Proceedings of the IEEE Power Engineering Society Summer Meeting, Chicago, IL, USA, 25July 2002; pp. 1148-1153.

53. Akorede, M.F.; Hizam, H.; Aris, I.; Kadir, M.Z.A.A. Effective method for optimal allocation of distributed generation units in meshed electric power systems. IETGener. Transm. Distrib. 2011, 5, 276-287.

54. Vinothkumar, K.; Selvan, M.P. Fuzzy embedded genetic algorithm method for distributed generation planning. Electr. PowerCompon. Syst. 2011, 39, 346-366. 
55. Kim, K.-H.; Song, K.-B.; Joo, S.-K.; Lee, Y.-J.; Kim, J.-O. Multiobjective distributed generation placement using fuzzy goal programming with genetic algorithm. Eur. Trans. Electr. Power2008, 18, 217-230.

56. Teng, J.-H.; Liu, Y.-H.; Chen, C.-Y.; Chen, C.-F. Value-based distributed generator placements for service quality improvements. Int. J.Electr. Power Energy Syst. 2007, 29, 268-274.

57. Prasanna, H.A.M.; Kumar, M.V.L.; Ananthpadmnabh, T. A Novel Approach for Optimal Allocation of a Distributed Generation in a Radial Distribution Feeder for Loss Minimization and Tail End Node Voltage Improvement during Peak Load; IJECES 2, No. I; Science and Education Publishing: New York, NY, USA, 2014; pp. 67-72.

58. Song, M.-P.; Gu, G.-C. Research on Particle Swarm Optimization: A Review. In Proceedings of the Third International Conference on Machine Learning and Cybernetics, Shanghai, China, 26-29 August2004, pp. 2216-2241.

59. Prommee, W.; Ongsakul, W. Optimal multiple distributed generation placement in microgrid system by improved reinitialized socialstructures particle swarm optimization. Eur. Trans. Electr. Power2011, 21, 489-504.

60. El-Zonkoly, A.M. Optimal placement of multi-distributed generation units including different load models using particle swarm optimisation. IETGener. Transm. Distrib. 2011, 5, 760-771.

61. Pandi, V.R.; Zeineldin, H.H.; Xiao, W. Determining optimal location and size of distributed generation resources considering harmonic and protection coordination limits. IEEE Trans. Power Syst. 2013, 28, 1245-1254.

62. Nayyar, A.; Singh, R. Ant Colony Optimization- Computational Swarm Intelligence Technique. In Proceedings of the International Conference on Computing for Sustainable Global Development, New Delhi, India, 16-18 March2016; pp. 1493-1499.

63. Wang, L.; Singh, C. Reliability-constrained optimum placement of reclosers and distributed generators in distribution networks using an ant colony system algorithm. IEEETrans. Syst.Man Cybern. CAppl. Rev. 2008, 38, 757-764.

64. Bi, X.; Wang, Y. An improved artificial bee colony algorithm. In Proceedings of the 3rd International Conference on Computer Research and Development (ICCRD), Shanghai, China, 11-13 March2011; pp. 174-177.

65. Abu-mouti, F.S.; El-Hawary, M.E. Heuristic Curve Fitted Technique for Distributed Generation Optimization in Radial Distribution Feeder System. LETGener. Transm. Distrib. 2009, 5, 172-180.

66. Suganthan, P.N. Differential evolution algorithm: Recent advances. In TPNC 2012. LNCS 7505; Dediu, A.-H., Martín-Vide, C., Truthe, B., Eds.; Springer: Heidelberg, Germany, 2012; pp. 30-46.

67. Arya, L.D.; Koshti, A.; Choube, S.C. Distributed generation planning using differential evolution accounting voltage stability consideration. Int. J. Electr. PowerEnergySyst. 2012, 42, 196-207.

68. Ammar, M.; Bouaziz, S.; Alimi, A.M.; Abraham, A. Hybrid Harmony Search algorithm for Global Optimization. In Proceedings of the Fifth World Congress on Nature and Biologically Inspired Computing, Fargo, ND, USA, 12-14 August 2013; pp. 69-75.

69. Rao, R.; Ravindra, K.; Satish, K.; Narasimham, S. Power loss minimization in distribution system using network reconfiguration in the presence of distributed generation. IEEE Trans. Power Syst. 2013, 28, 317-325.

70. Glover, F. Tabu search-Part I. ORSA J. Comput. 1989, 1, 190-206.

71. Nara, K.; Hayashi, Y.; Ikeda, K.; Ashizawa, T. Application of tabu search to optimal placement of distributed generators. In Proceedings of the IEEE Power Engineering Society Winter Meeting, New York, NY, USA, 28 January-1 February 2001; pp. 918-923.

72. Golshan, M.E.H.; Arefifar, S.A. Optimal allocation of distributed generation and reactive sources considering tap positions of voltage regulators as control variables. Eur. Trans. Electr. Power2007, 17, 219-239.

73. Abdelaziz, A.Y.; Hegazy, Y.G.; Mahmoud, W.E.M. Othman: A multi objective optimization for sizing and placement of voltage controlled distributed generation using supervised big bang-big crunch method. Electr. PowerCompon.Syst. 2015, 43, 105-117.

74. Arikiez, M.; Grasso, F.; Zito, M. Heuristic algorithm for coordinating smart houses in microgrid. In Proceedings of the2015 IEEE International Conference on Smart Grid Communications (SmartGridComm), Miami, FL, USA, 2-5November 2015; pp. 49-54. 
75. El-Khattam, W.; Bhattacharya, K.; Hegazy, Y.; Salama, M.M.A. Optimal investment planning for distributed generation in a competitive electricity market. IEEETrans. PowerSyst. 2004, 19, 1674-1684.

76. Hamedi, H.; Gandomkar, M. A straightforward approach to minimizing unsupplied energy and power loss through DG placement and evaluating power quality in relation to load variations over time. Int. J. Electr. PowerEnergySyst. 2012, 35, 93-96.

77. Banerjee, B.; Islam, S.M. Reliability based optimum location of distributed generation. Int. J. Electr. PowerEnergySyst. 2011, 33, 1470-1478.

78. Ghosh, S.; Ghoshal, S.P.; Ghosh, S. Optimal sizing and placement of distributed generation in a network system. Int. J. Electr. PowerEnergySyst. 2010, 32, 849-856.

79. Cavazos, J.; Moss, J.E.B.; O’Boyle, M.F. Hybrid optimizations: Which optimization algorithm to use? In Proceedings of the International Conference on Compiler Construction (ETAPS CC'06), Vienna, Austria, 30-31March 2006; Springer-Verlag: Vienna, Austria, 2006; pp. 185-201.

80. Kefayat, M.; Ara, A.L.; Niaki, S.N. A hybrid of ant colony optimization and artificial bee colony algorithm for probabilistic optimal placement and sizing of distributed energy resources. Energy Convers. Manag. 2015, 92, 149-161.

81. Gandomkar, M.; Vakilian, M.; Ehsan, M. A genetic-based tabu search algorithm for optimal DG allocation in distribution networks. Electr. PowerCompon. Syst. 2005, 33, 1351-1362.

82. Moradi, M.H.; Abedini, M. A combination of genetic algorithm and particle swarm optimization for optimal DG location and sizing in distribution systems. Int. J. Electr. PowerEnergySyst. 2012, 34, 66-74.

83. Sadeh, T.J.; Bashir, M.; Kamyab, E. Effect of distributed generation capacity on the coordination of protection system of distribution network. Proc. IEEE2010, doi: 110-115. 10.1109/TDC-LA.2010.5762869

84. Kennedy, J.; Ciufo, P.; Agalgaonkar, A. A review of protection systems for distribution networks embedded with renewable generation. Renew. Sustain. Energy Rev. 2016, 58, 1308-1317.

85. Singh, M. Protection coordination in distribution systems with and without distributed energy resources-A review. Prot. Control. Mod. PowerSyst. 2017, 2, 1-17.

86. Etemadi, A.H.; Fotuhi-Firuzabad, M. New considerations in modern protection system quantitative reliability assessment. IEEETrans. PowerDeliv. 2010, 24, 2213-2222.

87. Nimpitiwan, N.; Heydt, G.T.; Ayyanar, R.; Suryanarayanan, S. Fault current contribution from synchronous machine and inverter based distributed generators. IEEETrans. PowerDeliv. 2007, 22, 634-641.

88. Liao, S.-H. Expert system methodologies and applications: A decade review from 1995 to 2004. Expert Syst. Appl. 2005, 28, 93-103.

89. Park, D.H.; Kim, H.K.; Choi, I.Y.; Kim, J.K. A literature review and classification of recommender systems research. ExpertSyst.Appl.2012, 39, 10059-10072.

90. Tuitemwong, K.; Premrudeepreechacharn, S. Expert system for protection coordination of distribution system with distributed generators. Int. J.Electr. Power Energy Syst. 2011, 33, 466-471.

91. R.P. Broadwater, J.C. Thompson, S. Rahman, A. Sargent, "An expert system for integrated protection design with configurable distribution circuits. II", IEEE Transactions on Power Delivery, vol. 9, no. 2, pp. 1121-1128, April 1994.

92. Tuitemwong, K.; Premrudeepreechacharn, S. Expert System for Protective Devices Coordination in Radial Distribution Network with Small Power Producers. Knowl. Creation Diffus. Util.2007, 1159-1164, doi: 10.1109/PCT.2007.4538479

93. Lai, L.L. Development of an Expert System for Power System Protection Coordination. In Proceedings of the Fourth International Conference in Power System Protection, Edinburgh, UK, 11-13 April 1989; pp. 310-314.

94. L. L. Lai, An expert system used in power system protection. In Proceedings of the IFAC International Symposium, Seoul, Korea, 22-25 August 1989.

95. J. C. Tan, P. A. Crossley, D. Kirschen, J. Goody, J. A. Downes, "An expert system for the back-up protection of a transmission network", IEEE Transactions on Power Delivery, vol. 15, no. 2, pp. 508-514, April 2000.

96. Singh, M.; Vishnuvardhan, T.; Srivani, S.G. Adaptive protection coordination scheme for power networks under penetration of distributed energy resources. IET Gener. Transm. Distrib. 2016, 10, 3919-3929.

97. Girgis, A.; Brahma, S. Effect of distributed generation on protective device coordination in distribution system. In Proceedings of the LESCOPE'01 2001 Large Engineering Systems Conference onPower Engineering, Halifax, NS, Canada, 11-13 July2001; pp. 115-119. 
98. Brahma, S.M.; Girgis, A.A. Microprocessor-based reclosing to coordinate fuse and recloser in a system with high penetration of distributed generation. In Proceedings of the IEEE Power Engineering Society Winter Meeting, New York, NY, USA, 27-31 January2002; pp. 453-458.

99. Li, B.; Li, C.; Guo, F.; Xin, Y. Overcurrent protection coordination in a power distribution network with the active superconductive fault current limiter. IEEE Trans. Appl. Supercond.2014, 24, 1-4.

100. He, H.; Chen, L.; Yin, T.; Ren, L.Application of a SFCL for fault ride-through capability enhancement of DG in a microgrid system and relay protection coordination. IEEE Trans. Appl. Supercond.2016, 26, doi:10.1109/tasc.2016.2599898.

101. Elmitwally, A.; Gouda, E.; Eladawy, S. Optimal Application of Fault Current Limiters for Assuring Overcurrent Relays Coordination with Distributed Generations. ArbianJ. Sci. Eng. 2016, 41, 3381-3397.

102. Hadzi-Kostova, B.; Styczynski, Z. Network protection in distribution systems with dispersed generation. In Proceedings of the IEEE PES Transmission and Distribution Conference and Exhibition, Dallas, TX, USA, 21-24 May 2006; pp. 321-326.

103. Oudalov, A.; Fidigatti, A. Adaptive network protection in microgrids. Int. J. Distrib. EnergyResour. 2009, 5, 201-226.

104. Srinivas, S.T.P.; Swarup, K.S. Optimal relay coordination and communication based protection for micro-grid. In Proceedings of the IEEE Region 10 Symposium (TENSYMP), Kerala, India, 14-16 July2017.

105. Chunguang, Y.; Zhencun, P.; Wei, C.; Wei, W. The study on fault directional relay in protection system for distribution system under high dg penetration level. In Proceedings of the Asia-Pacific Power and Energy Engineering Conference, Wuhan, China, 27-31 March 2009; pp. 1-4.

106. Zamani, M.A.; Sidhu, T.S.; Yazdani, A. A protection strategy and microprocessor-based relay for low-voltage microgrids. IEEETrans. PowerDeliv. 2011, 26, 1873-1883.

107. Chen, J.; He, Z.Y.; Jiang, W. The overview of protection schemes for distribution systems containing micro-grid. In Proceedings of the Asia-Pacific Power and Energy Engineering Conference, Wuhan, China, 25-28 March 2011; pp. 1-4.

108. Nikkhajoei, H.; Lasseter, R.H. Microgrid Fault Protection Based on Symmetrical and Differential Current Components; Public Interest Energy Research California Energy Commission: Sacramento, CA, USA, 2006; pp. 1-72.

109. Saleh, K.A.; Zeineldin, H.H.; Al-Hinai, A.; El-Saadany, E.F. Optimal Coordination of Directional Overcurrent Relays Using a New Time-Current- Voltage Characteristic. IEEETrans. PowerDeliv. 2015, 30, 537-544.

110. Saleh, K.A.; Zeineldin, H.H.; El-Saanday, E.F. Dual-setting characteristic for directional overcurrent relays considering multiple fault locations. IETGener. Transm. Distrib. 2015, 99, 1332-1340.

111. Manohar, S.; Panigrahi, B.K.; Abhyankar, A.R. Optimal coordination of Directional Overcurrent Relays Using Teaching Learning-Based Optimization Algorithm. Int. J. Electr. PowerEnergySyst. 2013, 5, 33-41.

112. Mashayekhi, M.; Meskin, M.; Farahbakhsh, A. Impact of Size and Location of Distributed Generation on Overcurrent Relays in Active Distribution Networks. In Proceedings of the 49th North American Power Symposium (NAPS 2017), Morgantown, WV, USA, 17-19 September 2017; pp. 1-7.

113. Sa'ed, A.; Favuzza, S.; Ippolito, M.G.; Massaro, F. Investigating the Effect of Distributed Generators on Traditional Protection in Radial Distribution Systems. In Proceedings of the 2013 IEEE Power Tech, Grenoble, France, 16-20 June2013; pp. 1-6.

114. Walke, S.B.; Jangle, N.N.Impact of distributed generation on relay coordination. In Proceedings of the $\underline{2017}$ International Conference on Computing Methodologies and Communication (ICCMC), Erode, India, 8-19 July 2017.

115. Javadian SA, M.; Haghifam, M.-R.; Bathaee SM, T.; FotuhiFiroozabad, M. Adaptive centralized protection scheme for distribution systems with DG using risk analysis for protective devices placement. Electr. PowerEnergySyst. 2013, 44, 337-345.

116. E.A. Feilat \& K.N. Al-Tallaq (2005) An Artificial Neural Network Approach for Three-Zone Distance Protection,International Journal of an Simulation, 25:4, 291-298, DOI: $\underline{10.1080 / 02286203.2005 .11442342}$

117. M. Zayandehroodi, A. Mohamed, H. Shareef, M. Farhoodnea, "A novel neural network and backtracking based protection coordination scheme for distribution system with distributed generation", Int. J. Elect. Power Energy Syst., vol. 43, no. 1, pp. 868-879, Dec. 2012. 
118. Chelliah, T.R.; Thangaraj, R.; Allamsetty, S.; Pant, M. Coordination of directional over current relay using opposition based chaotic differential evolution algorithm. Int. J. Electr. PowerEnergy Syst. 2014, 55, 341-350.

119. Rezaei, N.; Haghifam, M.R. Protection scheme for a distribution system with distributed generation using neural networks. Int. J. Electr. PowerEnergySyst. 2008, 30, 235-241.

120. Perera, N.; Rajapakse, A.D. Agent-based protection scheme for distribution networks with distributed generators. In Proceedings of the Power Engineering Society General MeetingMontreal,Canada, 2006; p. 6.

121. Wayne Hong, H.; Chuen-Tsai, S.; Mesa, V.M.; Ng, S. Protective device coordination expert system. IEEETrans. PowerDeliv. 1991, 26, 359-365.

122. Zhu, Y.; Shaoqun, S.; Wang, D. Multiagent-based wide area protection with best-effort adaptive strategy. Electr. PowerEnergySyst. 2009, 31, 94-99.

123. Laaksonen, H.J. Protection principles for future microgrids. IEEETrans. PowerElectron. 2010, 25, $2910-2919$.

124. Ahmed H. Osman, Mohamed S. Hassan \& Mohamad Sulaiman, Communication-based Adaptive Protection for Distribution Systems Penetrated with Distributed Generators, Electric Power Components and Systems, 2015, 43:5, 556-565, DOI: 10.1080/15325008.2014.992500

125. Maiola, P.; Rolim, J. A Multi-Agent System for protection coordination of radial systems in the presence of distributed generation. In Proceedings of the 11th International Conference on Developments in Power Systems Protection, Birmingham, UK, 23-26 April 2012.

126. Katiraei, F.; Iravani, M.R.; Lehn, P.W. Micro-grid autonomous operation during and subsequent to islanding process. IEEETrans. PowerDeliv. 2005, 20, 284-292.

127. Chen, C.-R.; Lee, C.-H.; Chang, C.-J. Optimal Overcurrent relay coordination in power distribution system using a new approach. Electr. PowerEnergySyst. 2013, 45, 217-222.

128. Velasco, D.; Trujillo, C.L.; Garcera, G.; Figueres, E. Review of anti-islanding techniques in distributed generators. Renew. Sustain. EnergyRev. 2010, 14, 1608-1614.

129. Javadian, S.A.M.; Haghifam, M.-R.; Rezaei, N. A fault location and protection scheme for distribution systems in presence of dg using MLP neural networks. In Proceedings of the PES'09 Power and Energy Society General Meeting, Calgary, AB, Canada, 26-30 July 2009; pp. 1-8.

130. H.Wan, K.P. Wong and C.Y. Chung, "Multi-agent application in protection coordination of power system with distributed generations ", Power and Energy Society General Meeting - Conversion and Delivery of Electrical Energy in the 21st Century, pp. 1-6, 2008.

131. Thanga, C.R.; Srikanth, A. Coordination of Directional Overcurrent Relays using MATLAB/Simulink and their integration into undergraduate Power System Protection Courses. In Proceedings of the 10th International Conference on Advances in Power System Control, Operation and Management (APSCOM 2015),Hong Kong, China, 8-12 November2015.

132. Ekta, P.; Vishwakarma, D.N.; Singh, S.P. A new adaptive inverse-time protection scheme for modern distribution systems with distributed generation. In Proceedings of the 2017 IEEE Power and Energy Society Innovative Smart Grid Technologies Conference (ISGT), Washington, DC, USA, 23-26 April2017.

133. Chaitusaney, S.; Yokoyama, A. An appropriate distributed generation sizing considering recloser-fuse coordination. In Proceedings of the IEEE Power Engineering Society Transmission and Distribution Conferenceand Exhibition,Dalian, China, 23-25 August2005; pp. 1-6.

134. Sailaja, C.V.S.S.; Prasad, P.V.N. Determination of optimal distributed generation size for losses protection Co-ordination and reliability Evaluation Using ETAP. In Proceedings of the 2016 Biennial International Conference onPower and Energy Systems: Towards Sustainable Energy (PESTSE), Bengaluru, India, 21-23 January2016; pp. 1-6.

135. Chaitusaney, S.; Yokoyama, A. Impact of Protection Coordination on Sizes of Several Distributed Generation Sources. In Proceedings of the 7th International Power Engineering Conference (IPEC), Singapore, Singapore, 29 November-2 December2005; pp. 669-674.

136. Singh, M.; Panigrahi, B.K.; Abhyankar, A.R.; Mukherjee, R.; Kundu, R. Optimal location size and protection coordination of distributed generation in distribution network. In Proceedings of the 2013 IEEE Symposium on Swarm Intelligence (SIS), Singapore, Singapore, 16-19 April2013; pp. 221-227.

137. So, C.W.; Li, K.K. Protection relay coordination on ring-fed distribution network with distributed generations. In Proceedings of the TENCON'02 Conference on Computers, Communications, Control and Power Engineering, China, 28-31 October 2002; Volume 3, pp. 1885-1888 
138. Abbas, E.E.D.; Saeid, E.; Hossein, H. Co-optimization of Protection Coordination and Power Quality in Microgrids Using Unidirectional Fault Current Limiters. IEEE Trans. Smart Grid2017, doi: 10.1109/TSG.2017.2679281

139. Louw, C.; Buque, C.; Chowdhury, S. Modelling and simulation of an adaptive differential current protection scheme for a solar PV microgrid. In Proceedings of the 3rd Renewable Power Generation Conference (RPG 2014),Naples, Italy, $2^{\text {nd }}$ December, 2014, doi: 10.1049/cp.2014.0894

140. Lim, S.-I.; Choi, M,-S.; Lee, S.-J. Adaptive protection setting and coordination for power distribution systems. In Proceedings of the MEPCON 2006 Eleventh International Middle East Power Systems Conference, ElMinia, Egypt, 19-21 December 2006; Volume 1, pp. 129-134.

141. Wan, H.; Li, K.; Wong, K. An adaptive multiagent approach to protection relay coordination with distributed generators in industrial power distribution system. IEEE Trans. Ind. Appl. 2010, 46, 2118-2124.

142. Barzegari, M.; Fard, A.N.; Hamidi, M.M.; Shahrood, A.J. Optimal coordination of directional overcurrent relays in the presence of distributed generation using FCLs. In Proceedings of the 2010 IEEE International Energy Conference and Exhibition (EnergyCon), Manama, Bahrain, 18-22 December2010.

143. Gmez, J.C.; Morcos, M.M. Coordination of voltage sag and overcurrent protection in DG systems. IEEETrans. PowerDeliv. 2005, 20, 214-218.

144. Viawan, F.A.; Reza, M. The Impact of Synchronous Distributed Generation on Voltage Dip and Overcurrent Protection Coordination. In Proceedings of the IEEEInternational Conference on Future Power Systems Calgary, Canada, 2005.

145. Singh, M.K.; Parne, N.R. A fast Adaptive Protection Scheme for Distributed Generation Connected Networks with Necessary Relay Coordination. In Proceedings of the Engineering and Systems (SCES) 2013 Students Conference, Allahabad, India, 12-14April 2013; pp. 1-5.

146. Sharaf, H.M.; Zeineldin, H.H.; Ibrahim, D.K.; El, E.; el Zahab, D.A. Protection coordination of directional overcurrent relays considering fault current direction. In Proceedings of the 5th IEEE PES Innovative Smart Grid Technologies Europe (ISGT Europe), Istanbul, Turkey, 15-18October 2014; pp. 12-15.

147. Shih, M.Y.; Conde, A.; Leonowicz, Z.M.; Martirano, L. Mitigating the impact of distributed generation on directional overcurrent relay coordination by adaptive protection scheme. In Proceedings of the 16th IEEE International Conference on Environment and ElectricalEngineering, Florence, Italy, 7-10 June 2016; pp. 1-6.

148. Kumar, D.S.; Srinivasan, D.; Reindl, T.A. Fast and scalable protection scheme for distribution networks with distributed generation. IEEE Trans. Power Deliv. 2016, 31, 67-75.

149. Broadwater, R.P.; Thompson, J.C.; Rahman, S.; Sargent, A. An expert system for integrated protection design with configurable distribution circuits. II. IEEETransPowerDeliv. 1994, 9, 1121-1128.

150. Sortomme, E.; Venkata, S.S.; Mitra, J. Microgrid protection using communication-Assisted digital relays. IEEETrans. PowerDeliv. 2010, 25, 2789-2796.

151. He, J.; Liu, L.; Ding, F.; Li, C.; Zhang, D. A new coordinated backup protection scheme for distribution network containing distributed generation. In Protection and Control of Modern Power Systems; Springer: New York, NY, USA, 2016. 